Prepared in cooperation with the Federal Emergency Management Agency

\title{
Magnitude and Extent of Flooding at Selected River Reaches in Western Washington, January 2009
}

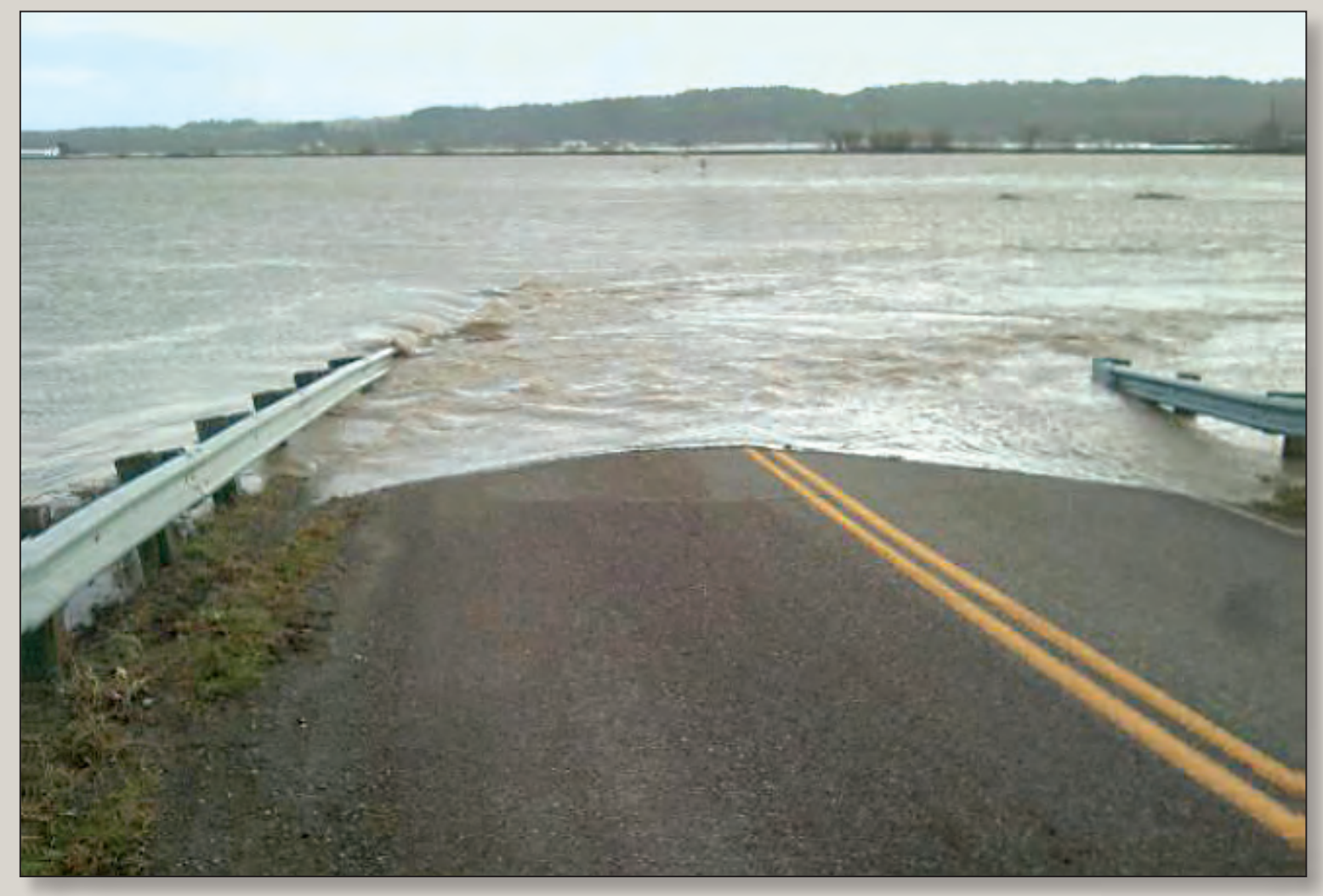

Scientific Investigations Report 2010-5177 
Cover: Stillaguamish River Valley, Washington, during the January 2009 flood (date unknown). Photograph from Washington State Department of Transportation, used with permission. 


\section{Magnitude and Extent of Flooding at Selected River Reaches in Western Washington, January 2009}

By M.C. Mastin, A.S. Gendaszek, and C.R. Barnas

Prepared in cooperation with the Federal Emergency Management Agency

Scientific Investigations Report 2010-5177 


\title{
U.S. Department of the Interior \\ KEN SALAZAR, Secretary
}

\section{U.S. Geological Survey \\ Marcia K. McNutt, Director}

\section{U.S. Geological Survey, Reston, Virginia: 2010}

\author{
For more information on the USGS - the Federal source for science about the Earth, its natural and living resources, \\ natural hazards, and the environment, visit http://www.usgs.gov or call 1-888-ASK-USGS \\ For an overview of USGS information products, including maps, imagery, and publications, \\ visit http://www.usgs.gov/pubprod \\ To order this and other USGS information products, visit http://store.usgs.gov
}

\begin{abstract}
Any use of trade, product, or firm names is for descriptive purposes only and does not imply endorsement by the U.S. Government.

Although this report is in the public domain, permission must be secured from the individual copyright owners to reproduce any copyrighted materials contained within this report.
\end{abstract}

Suggested citation:

Mastin, M.C., Gendaszek, A.S., and Barnas, C.R., 2010, Magnitude and extent of flooding at selected river reaches in western Washington, January 2009: U.S. Geological Survey Scientific Investigations Report 2010-5177, 34 p. 


\section{Contents}

Abstract
Pntroduction
Meteorological Conditions Leading to the Flood
Flooding in Western Washington
Magnitude of Flooding at the
$\quad$ Selected Reaches
$\quad$ Sullection of High-Water Mark Data
$\quad$ Cragging of High-Water Marks
Survey of High-Water Marks

\section{Plates}

Plate 1. Maps showing magnitude and extent of January 2009 flooding on river mile 0 to 8 , Newaukum River, Lewis County, Washington.

Plate 2. Maps showing magnitude and extent of January 2009 flooding on river mile 17.5 to 22.6, Puyallup River, Pierce County, Washington.

Plate 3. Maps showing magnitude and extent of January 2009 flooding on river mile 4.8 to 6.5, South Prairie Creek, Pierce County, Washington.

Plate 4. Maps showing magnitude and extent of January 2009 flooding on river mile 0.1 to 3.2, Cedar River, King County, Washington.

Plate 5. Maps showing magnitude and extent of January 2009 flooding on river mile 40.5 to 43.2, Snoqualmie River, King County, Washington.

Plate 6. Maps showing magnitude and extent of January 2009 flooding on river mile 22.9 to 28.0, Snoqualmie River and river mile 0 to 1.5, Tolt River, King County, Washington.

Plate 7. Maps showing magnitude and extent of January 2009 flooding on river mile 12.3 to17.7, Stillaguamish River, Snohomish County, Washington. 


\section{Figures}

Figure 1. Map showing stream reaches in western Washington at which the floods of January 2009 were documented

Figure 2. Microwave imagery showing the development of the atmospheric river heading directly for the west coast of Washington State

Figure 3. Map showing estimated 10-year, 24-hour precipitation for western Washington ... 7

Figure 4. Map showing rank of January 2009 peak discharge on non-regulated streams for the period of record at U.S. Geological Survey streamflow-gaging stations with 10 years or more of record in western Washington

Figure 5. Photograph of Interstate 5 near Chehalis, Washington, during the January 2009 flood.

Figure 6. Photograph of Newaukum Creek near Napavine, Washington .

Figure 7. Photograph of Puyallup River at Orting looking downstream at the Calastoga Bridge southwest of Orting, Washington, at river mile 21.3, taken after the peak of the January 2009 flood

Figure 8. Photograph of South Prairie Creek, Washington, January 7, 2009, showing flooding of the Community Center and Volunteer Park through a low spot in the grass levee

Figure 9. Photograph of Cedar River near Renton, Washington, near river mile 3, near the upstream end of the study reach. Photograph taken January 9, 2009

Figure 10. Photograph of Snoqualmie River at Snoqualmie, Washington, looking downstream just upstream of river mile 42 on January 9, 2009

Figure 11. Photograph of Tolt River and the Snoqualmie River at Carnation, Washington, on January 9, 2009.

Figure 12. Photograph of Snoqualmie River near Carnation, Washington, on January 9, 2009, looking eastward from the left bank to the right bank at partially submerged NE Carnation Farm Road at the end of the study reach

Figure 13. Photograph of Stillaguamish River Valley, Washington, during the January 2009 flood.

Figure 14. Graph showing flood-frequency plot for the Newaukum River near Chehalis, Washington, streamflow-gaging station 12025000, showing the Log-Pearson Type III and weighted independent estimate probability distributions and the annual peak discharges for the period of record through water year 2009

Figure 15. Graph showing flood-frequency plot for the Puyallup River near Orting, Washington, streamflow-gaging station 12093500, showing the Log-Pearson Type III and weighted independent estimate probability distributions and the annual peak discharges for the period of record through water year 2009

Figure 16. Graph showing flood-frequency plot for the South Prairie Creek at South Prairie, Washington, streamflow-gaging station 12095000, showing the Log-Pearson Type III and weighted independent estimate probability distributions and the annual peak discharges for the period of record through water year 2009

Figure 17. Graph showing flood-frequency plot for the Cedar River at Renton, Washington, streamflow-gaging station 12119000, showing the Log-Pearson Type III probability distributions and the annual peak discharges for the period of record through water year 2009 . 


\section{Figures-Continued}

Figure 18. Graph showing flood-frequency plot for the Snoqualmie River near Snoqualmie, Washington, streamflow-gaging station 12144500 , showing the Log-Pearson Type III and weighted independent estimate probability distributions and the annual peak discharges for the period of record through water year 2009

Figure 19. Graph showing flood-frequency plot for the Tolt River near Carnation, Washington, streamflow-gaging station 12148500 , showing the Log-Pearson Type III and weighted independent estimate probability distributions and the annual peak discharges for the period of record through water year 2009..... 19

Figure 20. Graph showing flood-frequency plot for the Snoqualmie River near Carnation, Washington, streamflow-gaging station 12149000 , showing the Log-Pearson Type III and weighted independent estimate probability distributions and the annual peak discharges for the period of record through water year 2009

Figure 21. Graph showing flood-frequency plot for the North Fork Stillaguamish River near Arlington, Washington, streamflow-gaging station 12167000, showing the Log-Pearson Type III and weighted independent estimate probability distributions and the annual peak discharges for the period of record through water year 2009

Figure 22. Example of a field sheet completed by the flagging team for high-water mark SA43 on the Stillaguamish River, Washington

Figure 23. Photograph of high-water mark (HWM) SP1 in Veterans Park on the left bank of South Prairie Creek at South Prairie, Washington, showing some of the flagging team tools

Figure 24. Photograph of U.S. Geological Survey hydrologist demonstrating the use of a pole-mounted laser range finder with angle encoder to compute the vertical offset from the high-water mark to the laser range finder mount point on the global positioning system (GPS) unit pole

Figure 25. Photograph of U.S. Geological Survey hydrologist lining up a home-made reflector on a mud line high-water mark to be surveyed remotely by an RTK GPS unit and a pole-mounted laser range finder

Figure 26. Map showing locations of all surveyed high-water marks in the Puyallup River near Orting, Washington, study reach in an interactive Google Maps application

Figure 27. Satellite view of the Puyallup River near Orting, Washington, study reach showing some of the surveyed high-water marks in an interactive Google Maps application and the attributes of individual high-water mark P0-22

Figure 28. Graph showing flood profile of the January 2009 flood on the Newaukum River reach in western Washington

Figure 29. Graph showing flood profile of the January 2009 flood on the Puyallup River reach in western Washington

Figure 30. Graph showing flood profile of the January 2009 flood on the South Prairie Creek reach in western Washington

Figure 31. Graph showing flood profile of the January 2009 flood on the Cedar River reach in western Washington

Figure 32. Graph showing flood profile of the January 2009 flood on the Snoqualmie River at Snoqualmie reach in western Washington 


\section{Figures-Continued}

Figure 33. Graph showing flood profile of the January 2009 flood on the Tolt River reach in western Washington

Figure 34. Graph showing flood profile of the January 2009 flood on the Snoqualmie River at Carnation reach in western Washington 31

Figure 35. Graph showing flood profile of the January 2009 flood on the Stillaguamish River reach in western Washington

\section{Tables}

Table 1. National Weather Service River Forecast Center's listing of streams observed or forecasted to be above minimum criteria on the morning of January 7, 2009, in western Washington

Table 2. Eight stream reaches selected by Federal Emergency Management Agency for mapping of flood inundation in western Washington

Table 3. Daily precipitation, snow on ground, and maximum temperatures of selected stations in western Washington during the January 2009 floods

Table 4. Peak discharge information for U.S. Geological Survey streamflow-gaging stations at or near the study reaches in western Washington

Table 5. Peak discharges and annual exceedance probabilities of the January 2009 flooding at U.S. Geological Survey streamflow-gaging stations at or near the selected study reaches in western Washington 16

Table 6. High-water mark ratings

Table 7. Vertical error at global positioning system survey checks at Washington State Department of Transportation survey monuments made during the high-water mark survey at the eight selected stream reaches in western Washington 


\section{Conversion Factors and Datums}

Inch/Pound to SI

\begin{tabular}{lcl}
\hline & \multicolumn{1}{c}{ Multiply } & \multicolumn{1}{c}{ To obtain } \\
\hline inch (in.) & Length & \\
inch (in.) & 2.54 & centimeter $(\mathrm{cm})$ \\
foot (ft) & 25.4 & millimeter $(\mathrm{mm})$ \\
U.S. survey foot (ft) & 0.3048 & meter $(\mathrm{m})$ \\
mile (mi) & 0.3048006 & meter $(\mathrm{m})$ \\
\hline & 1.609 & kilometer $(\mathrm{km})$ \\
\hline acre & Area & \\
acre & 4,047 & square meter $\left(\mathrm{m}^{2}\right)$ \\
square mile $\left(\mathrm{mi}^{2}\right)$ & 0.4047 & hectare $(\mathrm{ha})$ \\
square mile $\left(\mathrm{mi}^{2}\right)$ & 259.0 & hectare $(\mathrm{ha})$ \\
\hline & 2.590 & square kilometer $\left(\mathrm{km}^{2}\right)$ \\
\hline cubic yard $\left(\mathrm{yd}^{3}\right)$ & Volume & \\
acre-foot $(\mathrm{acre}-\mathrm{ft})$ & 0.7646 & cubic meter $\left(\mathrm{m}^{3}\right)$ \\
\hline & 1,233 & cubic meter $\left(\mathrm{m}^{3}\right)$ \\
\hline cubic foot per second $\left(\mathrm{ft}^{3} / \mathrm{s}\right)$ & Flow rate & \\
\hline
\end{tabular}

SI to Inch/Pound

\begin{tabular}{lcll}
\hline \multicolumn{1}{c}{ Multiply } & By & \multicolumn{1}{c}{ To obtain } \\
\hline centimeter $(\mathrm{cm})$ & Length & & \\
meter $(\mathrm{m})$ & 0.3937 & inch (in.) & \\
millimeter $(\mathrm{mm})$ & 3.281 & foot (ft) & \\
\hline
\end{tabular}

Temperature in degrees Fahrenheit $\left({ }^{\circ} \mathrm{F}\right)$ may be converted to degrees Celsius $\left({ }^{\circ} \mathrm{C}\right)$ as follows:

${ }^{\circ} \mathrm{C}=\left({ }^{\circ} \mathrm{F}-32\right) / 1.8$.

\section{Datums}

Vertical coordinate information is referenced to the North American Vertical Datum of 1988 (NAVD 88).

Horizontal coordinate information is referenced to the North American Datum of 1983 (NAD 83).

Elevation, as used in this report, refers to distance above the vertical datum. 
This page intentionally left blank 


\title{
Magnitude and Extent of Flooding at Selected River Reaches in Western Washington, January 2009
}

\author{
By M.C. Mastin, A.S. Gendaszek, and C.R. Barnas
}

\section{Abstract}

A narrow plume of warm, moist tropical air produced prolonged precipitation and melted snow in low-to-mid elevations throughout western Washington in January 2009. As a result, peak-of-record discharges occurred at many long-term streamflow-gaging stations in the region. A disaster was declared by the President for eight counties in Washington State and by May 2009, aid payments by the Federal Emergency Management Agency (FEMA) had exceeded $\$ 17$ million. In an effort to document the flood and to obtain flood information that could be compared with simulated flood extents that are commonly prepared in conjunction with flood insurance studies by FEMA, eight stream reaches totaling 32.6 miles were selected by FEMA for inundation mapping. The U.S. Geological Survey's Washington Water Science Center used a survey-grade global positioning system (GPS) the following summer to survey high-water marks (HWMs) left by the January 2009 flood at these reaches. A Google Maps $($ application was developed to display all HWM data on an interactive mapping tool on the project's web site soon after the data were collected. Water-surface profiles and maps that display the area and depth of inundation were produced through a geographic information system (GIS) analysis that combined surveyed HWM elevations with Light Detection and Ranging (LiDAR)-derived digital elevation models of the study reaches and surrounding terrain. In several of the reaches, floods were well confined in their flood plains and were relatively straightforward to map. More common, however, were reaches with more complicated hydraulic geometries where widespread flooding resulted in flows that separated from the main channel. These proved to be more difficult to map, required subjective hydrologic judgment, and relied on supplementary information, such as aerial photographs and descriptions of the flooding from local landowners and government officials to obtain the best estimates of the extent of flooding.

\section{Introduction}

Heavy rains began on January 6, 2009, and air temperatures began to rise throughout western Washington. The heavy rains were forecasted to continue, major flooding was expected, and the Federal Emergency Management Agency (FEMA) office in Bothell, Washington, was placed in an "Awareness" notification mode for river flooding, indicating that a potential or developing hazardous situation was occurring. The rains continued through January 8, 2009, resulting in flooding on most rivers and creeks in western Washington. Evacuation orders had been issued on January 7 to residents near the Puyallup and Carbon Rivers and those near South Prairie Creek. At that time, many of the rivers were already above bankfull and (or) flood stage and forecasted to rise higher (table 1). A section of Interstate 5, the main north-south transportation route in western Washington, was flooded, and the highway was closed for 43 hours near Chehalis, Washington; this closure resulted in an economic loss of $\$ 12$ million per day (per letter from Governor Christine Gregoire to the President, January 21, 2009). On January 21, the Governor requested that the President declare a disaster for nine counties in Washington (Clark, King, Lewis, Mason, Pacific, Pierce, Snohomish, Thurston, and Wahkiakum). On January 30, 2009, the President declared such a disaster, and by May 2009, FEMA disaster aid had exceeded $\$ 17$ million.

After the flood, FEMA requested that the U.S. Geological Survey (USGS) Washington Water Science Center (WAWSC) document the flood to provide information needed for verification of flood simulation models to be used for current and future flood-insurance studies.

\section{Purpose and Scope}

This report documents the magnitude and estimates of the extent of flooding at eight stream reaches (selected by FEMA) in western Washington in January 2009 (fig. 1, table 2) and the methods used to define the extent of flooding. 
Table 1. National Weather Service River Forecast Center's listing of streams observed or forecasted to be above minimum criteria on the morning of January 7, 2009, in western Washington.

[Flow is in cubic feet per second. Stage is in feet. Abbreviations: NWS ID, National Weather Service identifier; NF, north fork; $\%$, percent]

Retrieved 01/07/2009@10:33 PST, by jclemens@usgs.gov

WASHINGTON Streams Observed or Forecasted to be Above a Minimum Criteria

Source: http//www. nwifc.noaa.qovl

\begin{tabular}{|c|c|c|c|c|c|c|c|}
\hline \multirow[b]{2}{*}{ Locarion } & \multirow[b]{2}{*}{ NWS ID } & \multirow[b]{2}{*}{$\begin{array}{l}\text { Gurrent } \\
\text { Flow }\end{array}$} & \multirow[b]{2}{*}{$\begin{array}{l}\text { Gurrem } \\
\text { Stage }\end{array}$} & \multirow[b]{2}{*}{$\begin{array}{l}\text { Flood } \\
\text { Stage }\end{array}$} & \multicolumn{3}{|c|}{$\square$ simulatod (Striped) } \\
\hline & & & & & $\begin{array}{c}\text { Bankfull } \\
\text { Stage }\end{array}$ & $\begin{array}{l}\text { Gurrem } \\
\text { Status }\end{array}$ & Forecasied \\
\hline NF STILLAGUAMISH-NEAR ARLINGTON & ARGW1 & 38500 & 14.45 & 13 & 10.7 & Above Flood & Above Flood \\
\hline GREEN-NEAR AUBURN & AUBW1 & 8640 & 61.42 & 64 & 60.7 & Above Bankfull & Above Bankfull \\
\hline SKOOKUMCHUCK-NEAR BUCODA & BCDW1 & 1862 & 10.18 & 13.5 & 11.5 & $80 \%$ Bankfull & Above Flood \\
\hline BOGACHIEL-NEAR LAPUSH & BOGW1 & & 41.61 & 37 & 35 & Alsove Flood & Below Criteria \\
\hline CHEHALIS-AT CENTRALIA & CENW1 & 10172 & 58.76 & 65 & 61 & $90 \%$ Bankfull & Above Flood \\
\hline CHEHALIS-NEAR GRAND MOUND & CGMW1 & 13232 & 11.13 & 14 & 12.2 & $90 \%$ Bankfull & Above Flood \\
\hline NACHES-NEAR CLIFFDEL & CLFW1 & 1030 & 28.33 & 31 & 29 & $90 \%$ Bankfull & Above Bankfull \\
\hline SKAGIT-NEAR CONCRETE & CONW1 & 28803 & 21.56 & 28 & 23.5 & $90 \%$ Bankfull & Above Flood \\
\hline SNOQUALMIE-NEAR CARNATION & CRNW1 & 26010 & 56.05 & 54 & 51 & Above Flood & Above flood \\
\hline CHEHALIS-AT PORTER & CRPW1 & 22800 & 19.54 & 21 & 18 & Above Bankfull & Above Flood \\
\hline YAKIMA-AT EASTON & EASW1 & 3799 & 51.04 & 51.3 & 51.1 & $90 \%$ Bankfull & $90 \%$ Bankfull \\
\hline ELWHA-AT MCDONALD BRIDGE & ELWW1 & 8713 & 16.19 & 20 & 17.3 & $90 \%$ Bankfull & Above Bankfull \\
\hline CARBON-NEAR FAIRFAX & FFXW1 & 9582 & 14.86 & 13.5 & 11.6 & Above Flood & Above Flood \\
\hline SF STILLAGUAMISH-NEAR GRANITE FALLS & GFLW1 & 19366 & 14.17 & 14 & 12.9 & Alsove Flood & Above Flood \\
\hline SKYKOMISH-NEAR GOLD BAR & GLBW1 & 50838 & 16.75 & 15 & 12.2 & Above Flood & Above Flood \\
\hline HANGMAN CREEK-AT SPOKANE & HAGW1 & 148 & 2.05 & 11 & 10 & Below Criteria & $90 \%$ Bankfull \\
\hline YAKIMA-NEAR HORLICK & HLKW1 & 6300 & 32.83 & 35.6 & 34.5 & $90 \%$ Bankfull & Above Bankfull \\
\hline ISSAQUAH CREEK-NEAR MOUTH & ISSW1 & 1845 & 10.76 & 10.5 & 8.1 & Above Flood & Below Criteria \\
\hline COWLITZ-AT KELSO & KELW1 & & 20.4 & 21.5 & 18 & Above Bankfull & Above Flood \\
\hline YAKIMA-AT KIONA & KIOW1 & 2444 & 4.47 & 13 & 11 & Below Criteria & Above Bankfull \\
\hline CEDAR-NEAR LANDSBURG & LNDW1 & 2933 & 4,51 & 5 & 3.5 & Above Bankfull & Above Flood \\
\hline COLUMBIA-AT LONGVIEW & LOPW1 & & 10.78 & 13.5 & 12 & $80 \%$ Bankfull & Above Bankfull \\
\hline LEWIS-AT WOODLAND & LRWW1 & & 21.33 & 24 & 22 & $90 \%$ Bankfull & $90 \%$ Bankfull \\
\hline NOOKSACK-AT FERNDALE & NKSWV1 & 20300 & 16.18 & 19 & 15 & Above Bankfull & Above Flood \\
\hline NOOKSACK-AT CEDARVILLE & NRKW1 & 48600 & 148,46 & 146.5 & 144.8 & Above Flood & Above flood \\
\hline SF NOOKSACK-AT SAXON BRIDGE & NSSW1 & 10478 & 7.69 & 8 & 6.7 & Above Bankfull & Above Flood \\
\hline PUYALLUP-NEAR ORTING & ORTW1 & 11895 & 9.78 & 7.31 & 6.27 & Above Flood & Above Flood \\
\hline COWLITZ-AT PACKWOOD & $\overline{\text { PACW1 }}$ & 12400 & 6.06 & 10.5 & 8.2 & Below Criteria & Above Flood \\
\hline YAKIMA-NEAR PARKER & PARW1 & 2398 & 4,14 & 10 & 9.4 & Below Criteria & Above Flood \\
\hline KLICKITAT-NEAR PITT & PITW1 & 4348 & 6.81 & 9 & 9 & Below Criteria & $90 \%$ Bankfull \\
\hline PUYALLUP-AT PUYALLUP & PUYW1 & 29173 & 25.14 & 30 & 24 & Above Bankfull & Above Flood \\
\hline COWLITZ-AT RANDLE & RAWW1 & 12597 & 14.75 & 18 & 13.2 & Above Bankfull & Above Flood \\
\hline CEDAR-AT RENTON & RNTW1 & 3488 & 11.41 & 12 & 10,4 & Above Bankfull & Above flood \\
\hline SATSOP-NEAR SATSOP & $\overline{\text { SATW1 }}$ & 36633 & 36.67 & 34 & 31.5 & Aloove Flood & Above Flood \\
\hline SNOHOMISH-AT SNOHOMISH & SNAW1 & 40914 & 22.84 & 25 & 20 & Above Bankfull & Above Flood \\
\hline SNOQUALMIE-NEAR SNOQUALMIE & SQUW1 & 41107 & 17.75 & 13.5 & 12.7 & Above Flood & Above Flood \\
\hline SKOKOMISH-NEAR POTLATCH & SRPW1 & 18617 & 16.8 & 16 & 14 & Above Flood & Above Flood \\
\hline WALLA WALLA-NEAR TOUCHET & $\overline{\mathrm{TCHW} 1}$ & 3040 & 8.68 & 13 & 10 & $80 \%$ Bankfull & Above Flood \\
\hline TOLT-NEAR CARNATION & $\overline{\text { TOLW1 }}$ & 0 & 11.59 & 8.9 & 7.7 & Above Flood & Above Flood \\
\hline TOUTLE-AT TOWER BRIDGE & $\overline{\text { TOTW1 }}$ & 20100 & 13.03 & 25 & 22 & Below Criteria & Above Bankfull \\
\hline YAKIMA-AT UMTANUM & UMTW1 & 2777 & 32.27 & 35.5 & 33.5 & $90 \%$ Bankfull & Above Bankfull \\
\hline COLUMBIA-AT VANCOUVER & VAPW1 & & 9,79 & 16 & 15 & Below Criteria & $80 \%$ Bankfull \\
\hline COLUMBIA-AT WAUNA & WAUO3 & & 10.61 & 11.5 & 11.5 & $90 \%$ Bankfull & $90 \%$ Bankfull \\
\hline WILLAPA-NEAR WILLAPA & WILW1 & 9196 & 19.85 & 21 & 19 & Above Bankfull & Above Flood \\
\hline
\end{tabular}




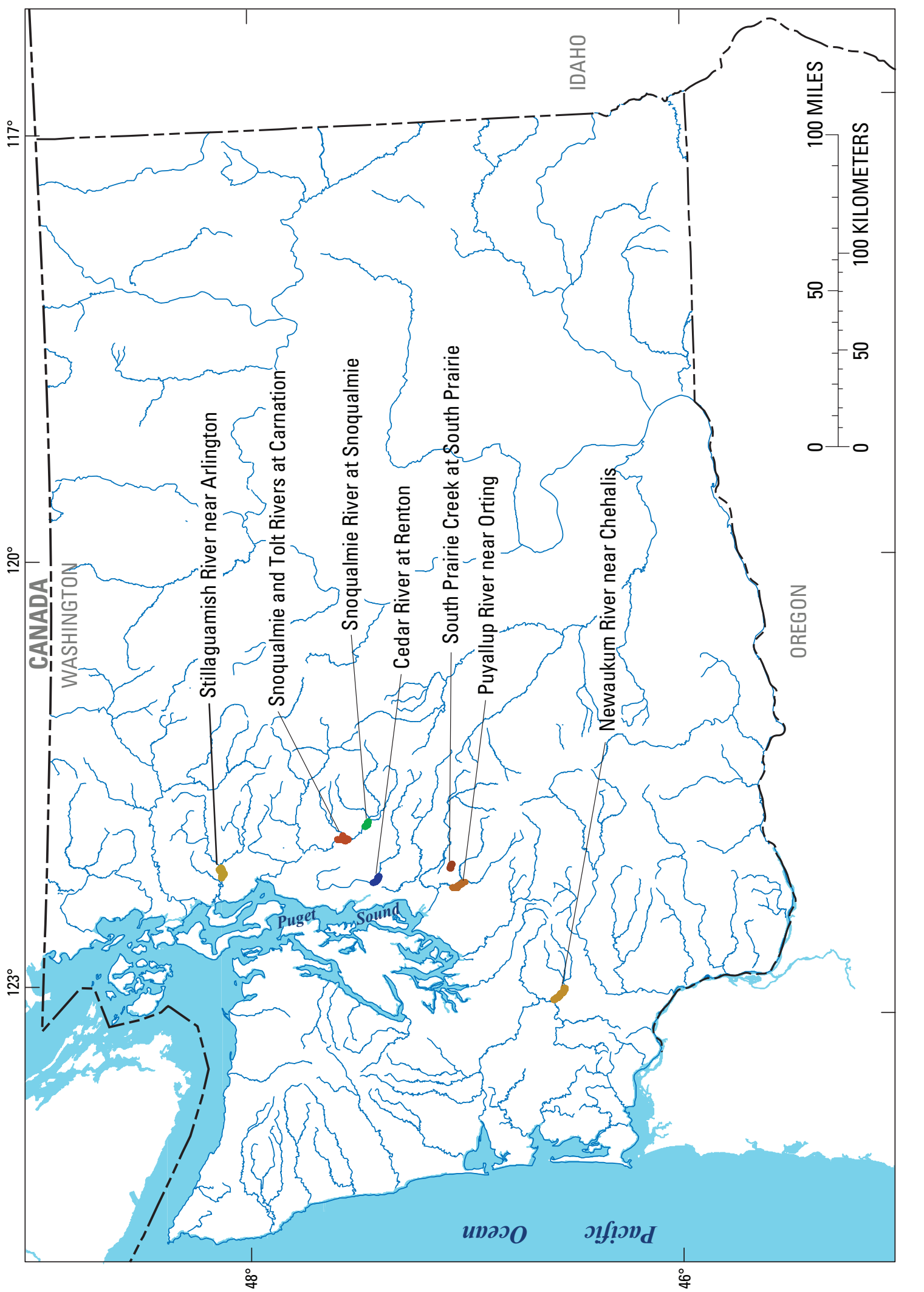

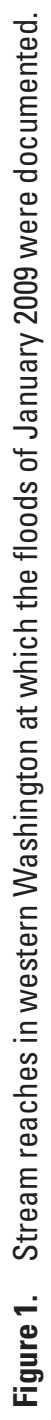


Table 2. Eight stream reaches selected by Federal Emergency Management Agency for mapping of flood inundation in western Washington.

[Abbreviations: RM, river mile, as noted in USGS 7.5 minute topographic maps; mi, mile]

\begin{tabular}{lcrc}
\hline \multicolumn{1}{c}{ Reach } & $\begin{array}{c}\text { Starting } \\
\text { RM }\end{array}$ & $\begin{array}{c}\text { Ending } \\
\text { RM }\end{array}$ & $\begin{array}{c}\text { Length } \\
\text { of study } \\
\text { reach } \\
\text { (mi) }\end{array}$ \\
\hline Newaukum River near Chehalis & 0.0 & 8.0 & 8.0 \\
Puyallup River near Orting & 17.5 & 22.6 & 5.1 \\
South Prairie Creek at South Prairie & 4.8 & 6.5 & 1.7 \\
Cedar River at Renton & .1 & 3.2 & 3.1 \\
Snoqualmie River at Snoqualmie & 40.5 & 43.2 & 2.7 \\
Snoqualmie River at Carnation & 22.9 & 28.0 & 5.1 \\
Tolt River at Carnation & 0 & 1.5 & 1.5 \\
Stillaguamish River near Arlington & 12.3 & 17.7 & 5.4 \\
$\quad$ Total length & & & 32.6 \\
\hline
\end{tabular}

The magnitude of the floods at these reaches was determined by estimating the exceedance probabilities for the flood on the basis of annual peak streamflow data from nearby longterm streamflow-gaging stations operated by the USGS. The extent of flooding was determined by mapping high-water marks (HWMs) and creating flood-depth maps and peak water-surface profiles. The maps and profiles were developed from surveyed HWMs collected by the USGS WAWSC during the summer of 2009. Geographic Information System (GIS) techniques were used to delineate the extent and depth of the flooding based on HWMs, aerial photographs of the flooding, and local knowledge of the flood shared by local officials and residents. Many of the selected reaches are currently being evaluated by FEMA for a Flood Insurance Study (FIS) or are scheduled for an FIS in the near future.

\section{Meteorological Conditions Leading to the Flood}

Washington was receiving significant rainfall by January 5, 2009, and the rains continued to be heavy through January 8, 2009. The weather system has been described as an "atmospheric river" or "Pineapple Express" (alluding to its origin in the Pacific Ocean near the Hawaiian Islands) consisting of strong westerly flow aloft with embedded sub-tropical moisture (Shick, 2009). Atmospheric rivers are elongated, narrow bands of relatively warm winds funneled from the subtropics that carry substantial moisture (fig. 2), and they are associated with all major and most moderate flooding in western Washington (Shick, 2009). Such warm winds occur at all times during the year, but typically are strongest from October to March.

Typical winter wet weather for the Pacific Northwest had recharged the dry fall soils with moisture prior to the heavy rains that began January 6, 2009. Also at this time, air temperatures began to rise (table 3 ). The rains continued to be heavy through January 8, resulting in 3-day totals of more than 7.5 in. at many locations in western Washington (table 3 ) with higher precipitation totals at the highest elevations. A thin blanket of snow covered most of the lowlands in western Washington prior to the heavy rains and increased in depth with increased elevation. By January 10, the snow had melted in the lowlands and was significantly thinned at mid-elevations. The highest 24-hour rainfall totals were approximately equivalent to that of the estimated 10 -year, 24-hour rainfall for western Washington (fig. 3). Major flooding in most of western Washington's rivers followed in response to several days of heavy rain and contributions from snowmelt.

\section{Flooding in Western Washington}

The January 2009 flooding was widespread throughout western Washington, setting peaks of record at 21 nonregulated rivers at streamflow-gaging stations operated by the USGS for more than 10 years (fig. 4). Although the 24-hour precipitation totals reflect an event with a return interval of about 10 years (fig. 3), the January 2009 peak flows at many of the streamflow-gaging stations with 50-80 years of record suggest that it was a flooding event with a return interval much greater than 10 years. Factors other than the 24-hour precipitation totals added to the severity of the flooding. For example, the nearly continuous precipitation for several days prior to the flood would likely have brought the soil moisture levels to field capacity, priming them to yield rapid runoff with any additional rain or snowmelt. Additionally, the disappearance of lowland snow cover present prior to the flood suggests that snowmelt contributions were important to the magnitude of the floods. 
(um) dąe $M$ ㄹqํ!!

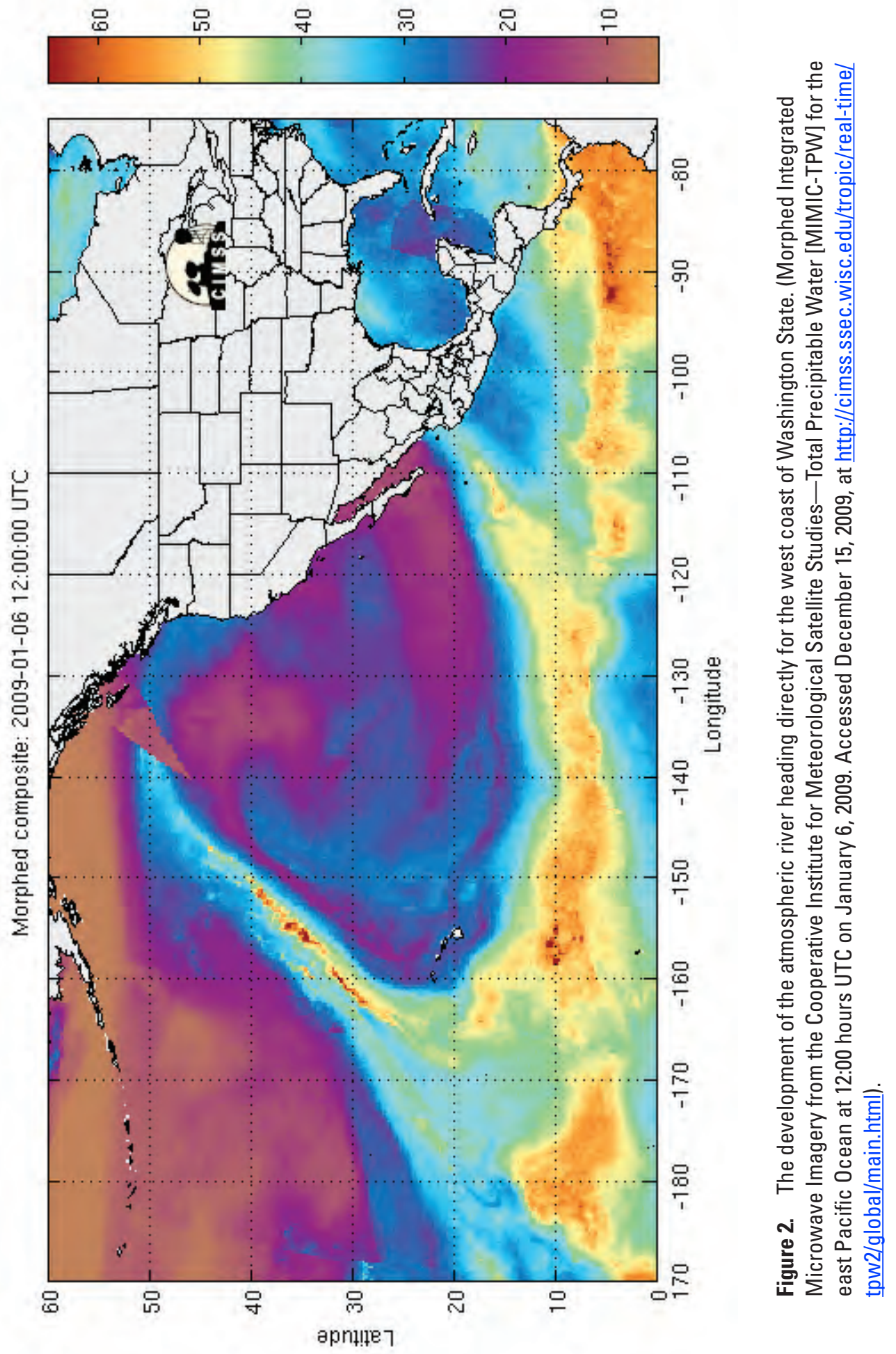




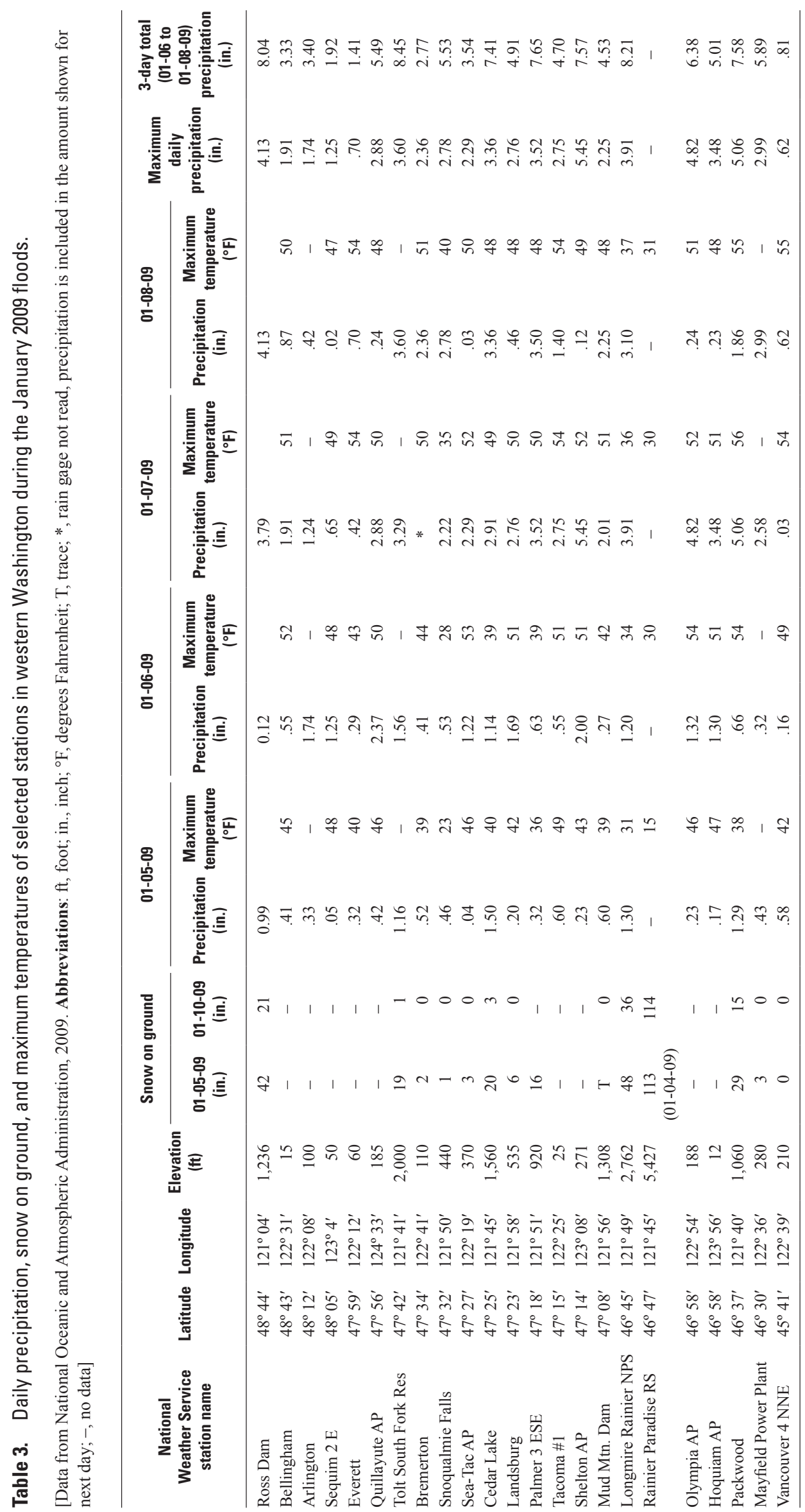




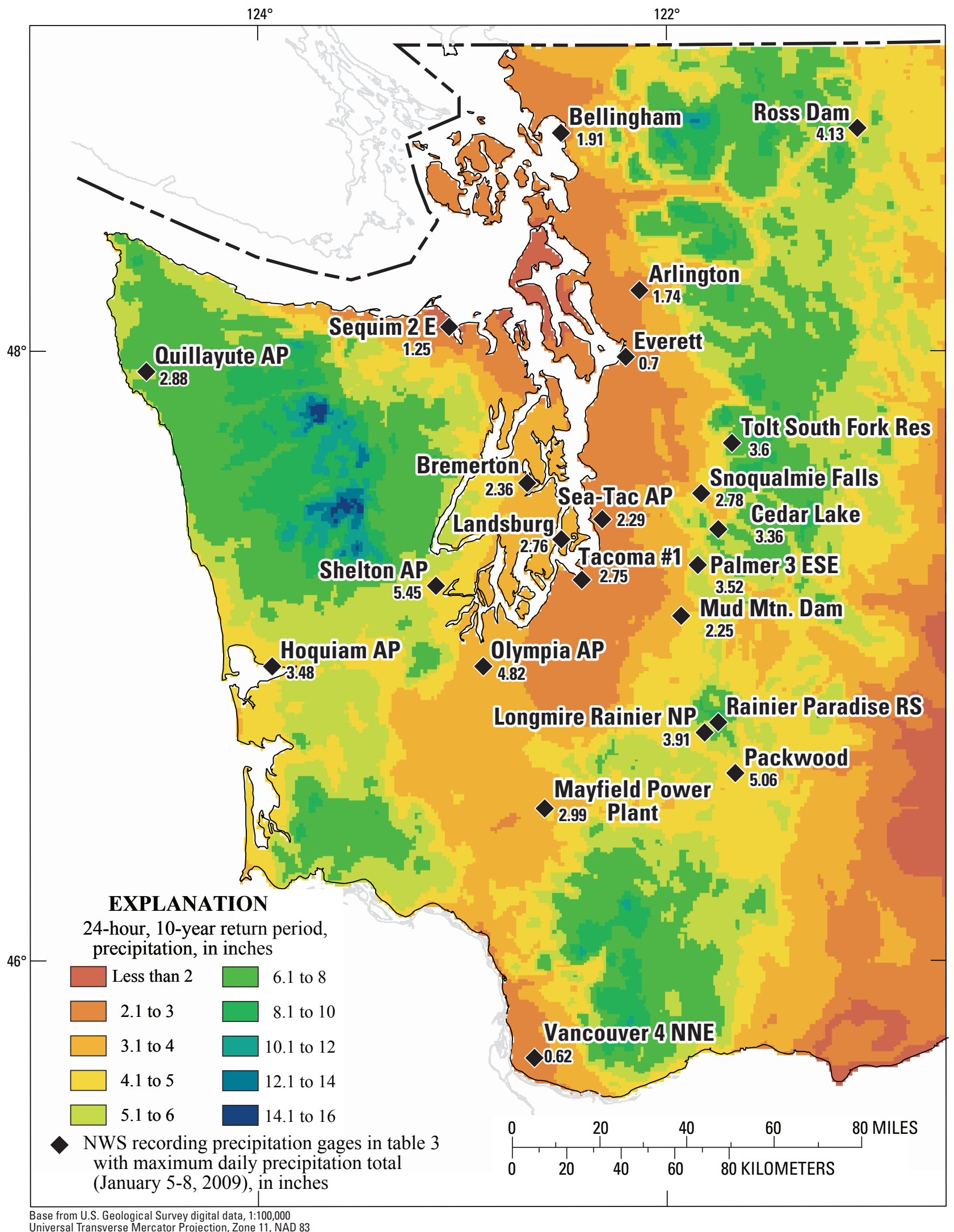

Figure 3. Estimated 10-year, 24-hour precipitation for western Washington. The maximum reported daily precipitation for the period January 5-8, 2009, for precipitation gages shown in table 3. Precipitiation data from Taylor (2002). 


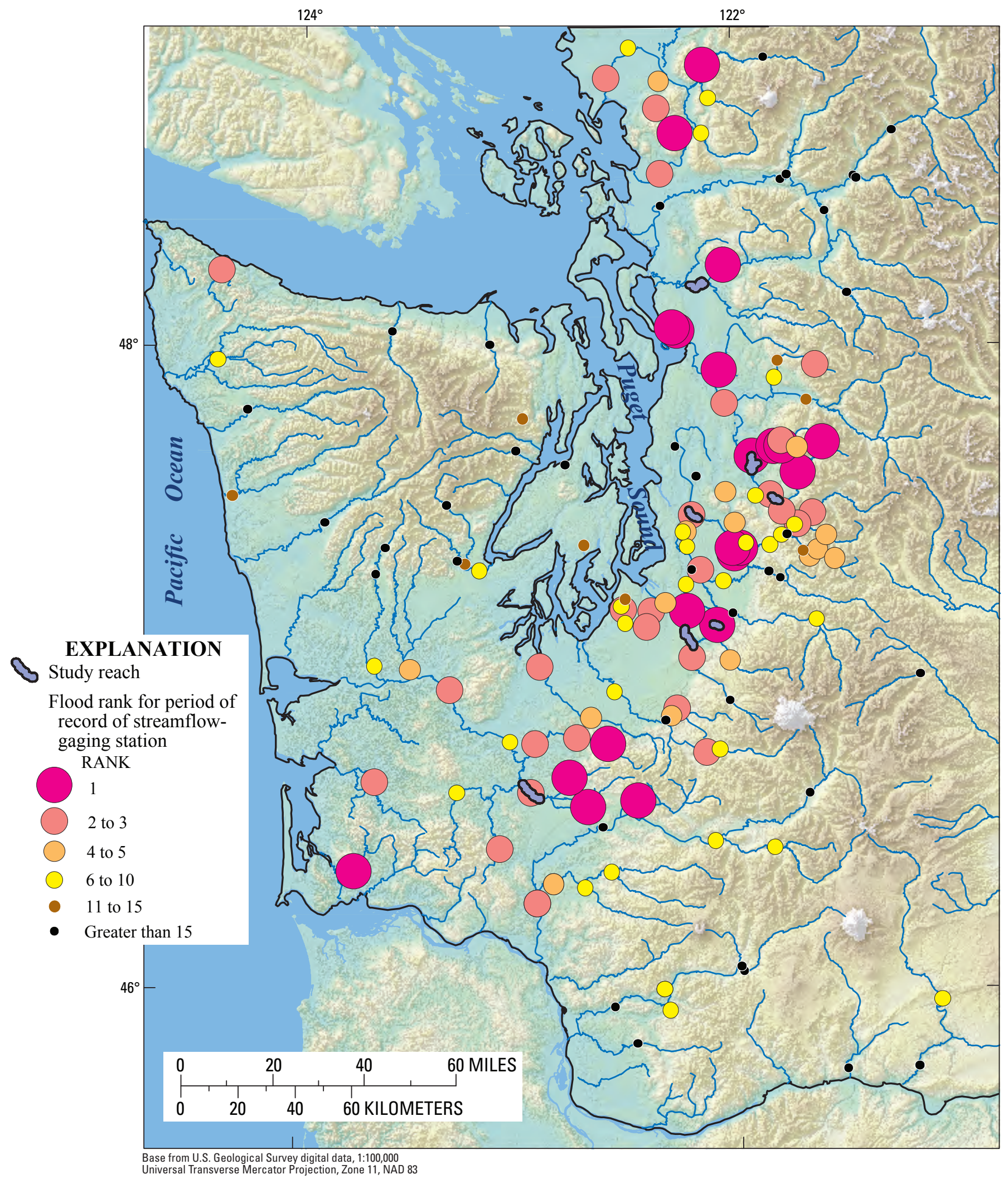

Figure 4. Rank of January 2009 peak discharge on non-regulated streams for the period of record at U.S. Geological Survey streamflow-gaging stations with 10 years or more of record in western Washington. 


\section{Magnitude of Flooding at the} Selected Reaches

All selected study reaches drain the western slopes of the Cascade Range in Washington and have drainage areas ranging from $79.5 \mathrm{mi}^{2}$ (South Prairie Creek) to $603 \mathrm{mi}^{2}$ (Snoqualmie River near Carnation) (table 4). The magnitudes of the floods in the selected reaches were some of the largest in western Washington in recent history. Comparisons of the peak discharges in January 2009 with other recorded peak discharges at the streamflow-gaging stations along with photographs of the flooding and a comparison of the January 2009 peak discharge with the discharges for various exceedance probabilities are provided here to convey a sense of the size of this flood.

The January 2009 flood produced peak of record flows at four of the eight streamflow-gaging stations in or near the selected study reaches (table 4). The period of record at these streamflow-gaging stations range from 51 to 81 years, thus providing a good indicator of the range in magnitude of flooding in western Washington over the last half century. The following photographs (figs. 5-13) provide a glimpse of the January 2009 flooding at the selected study reaches.

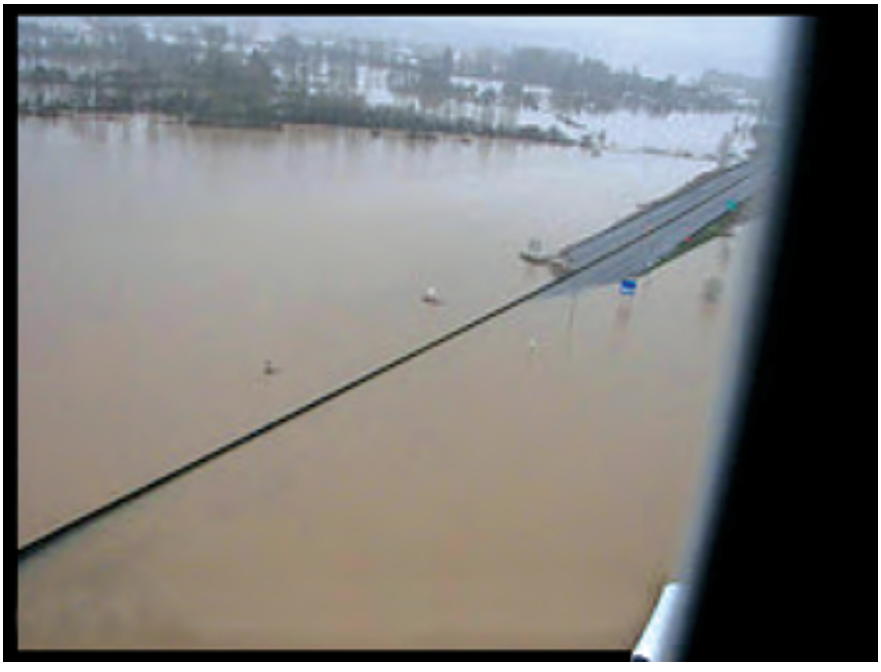

Figure 5. Interstate 5 near Chehalis, Washington, during the January 2009 flood. Source: Washington State Department of Transportation, Aerial Photography Branch. 


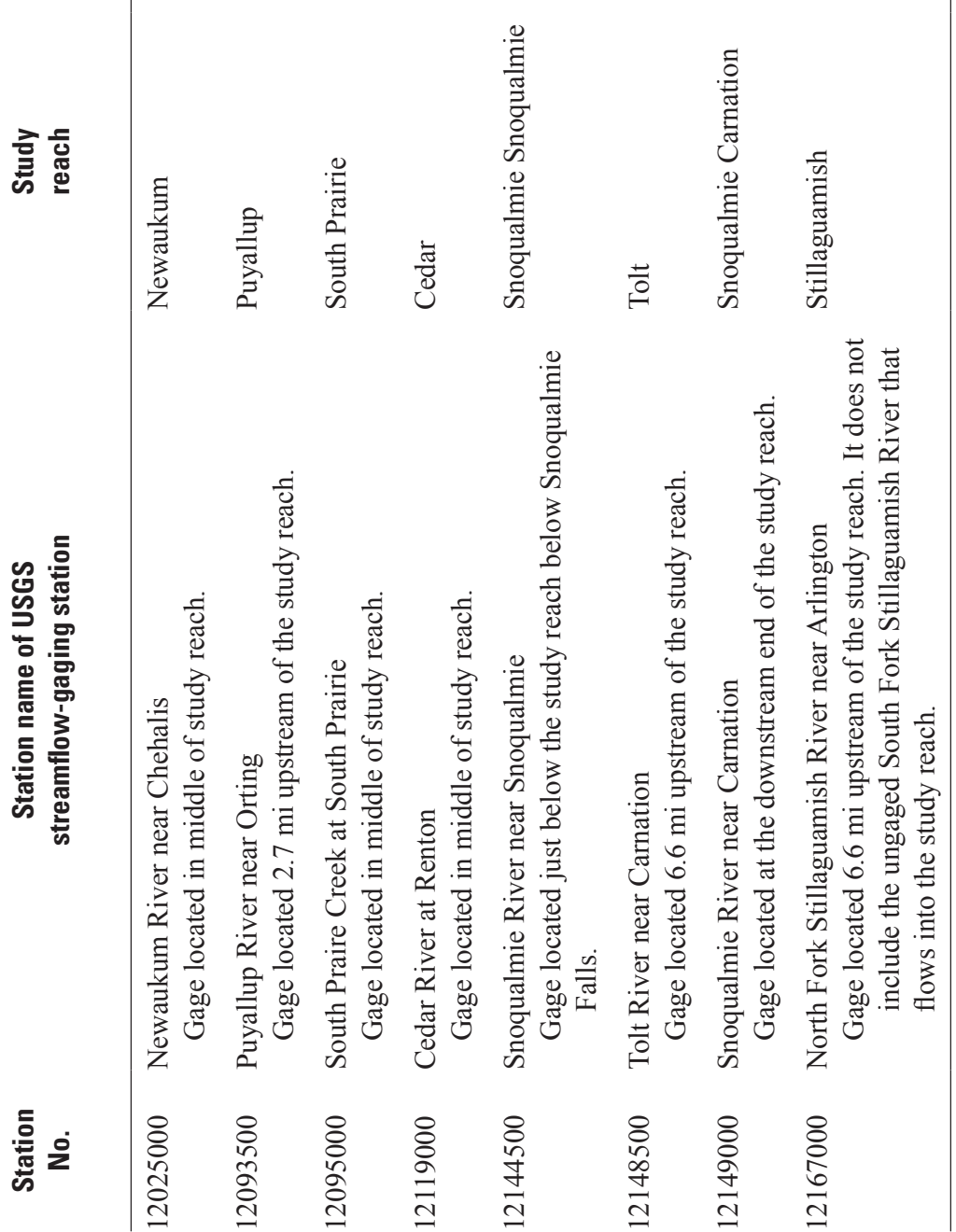




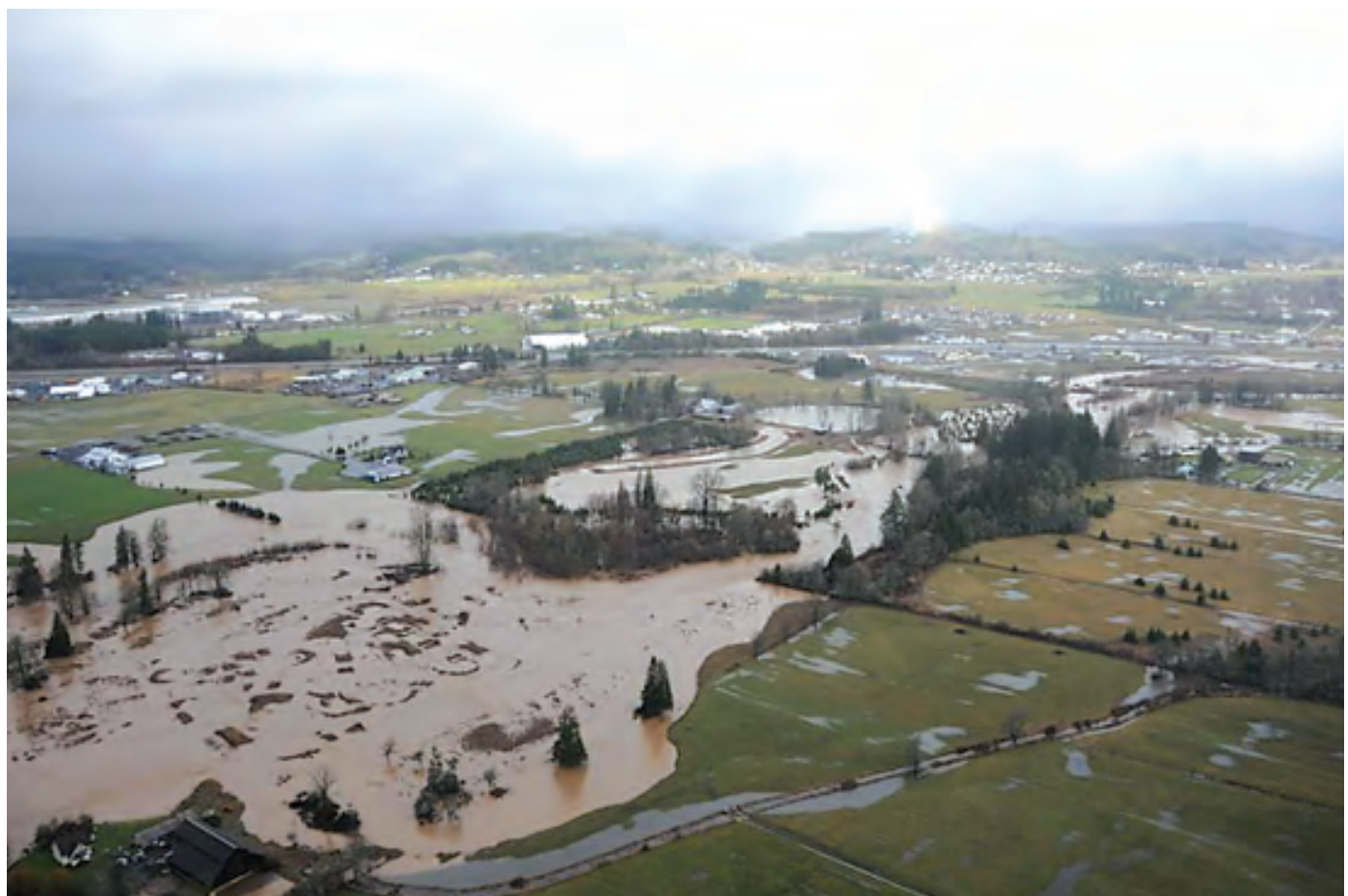

Figure 6. Newaukum Creek near Napavine, Washington, looking northeast. Flow direction is from right center to lower left of photograph. Source: Washington State Department of Transportation, Aerial Photography Branch, taken on the afternoon of January 8, 2009.

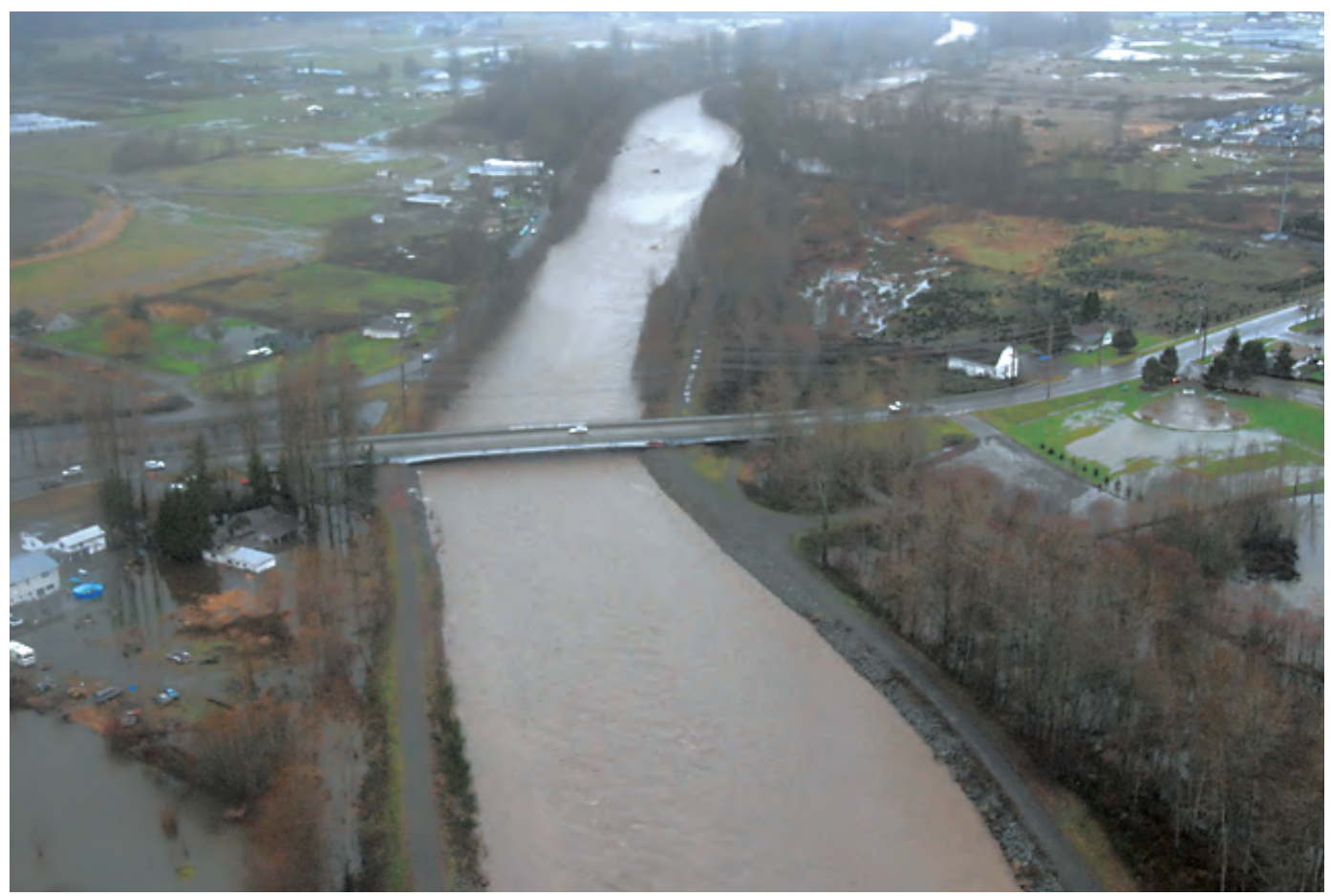

Figure 7. Puyallup River at Orting looking downstream at the Calastoga Bridge southwest of Orting, Washington, at river mile 21.3, taken after the peak of the January 2009 flood. Source: Washington State Department of Transportation, Aerial Photography Branch, provided by Randy Brake, Pierce County Surface-Water Management, September 2009. 


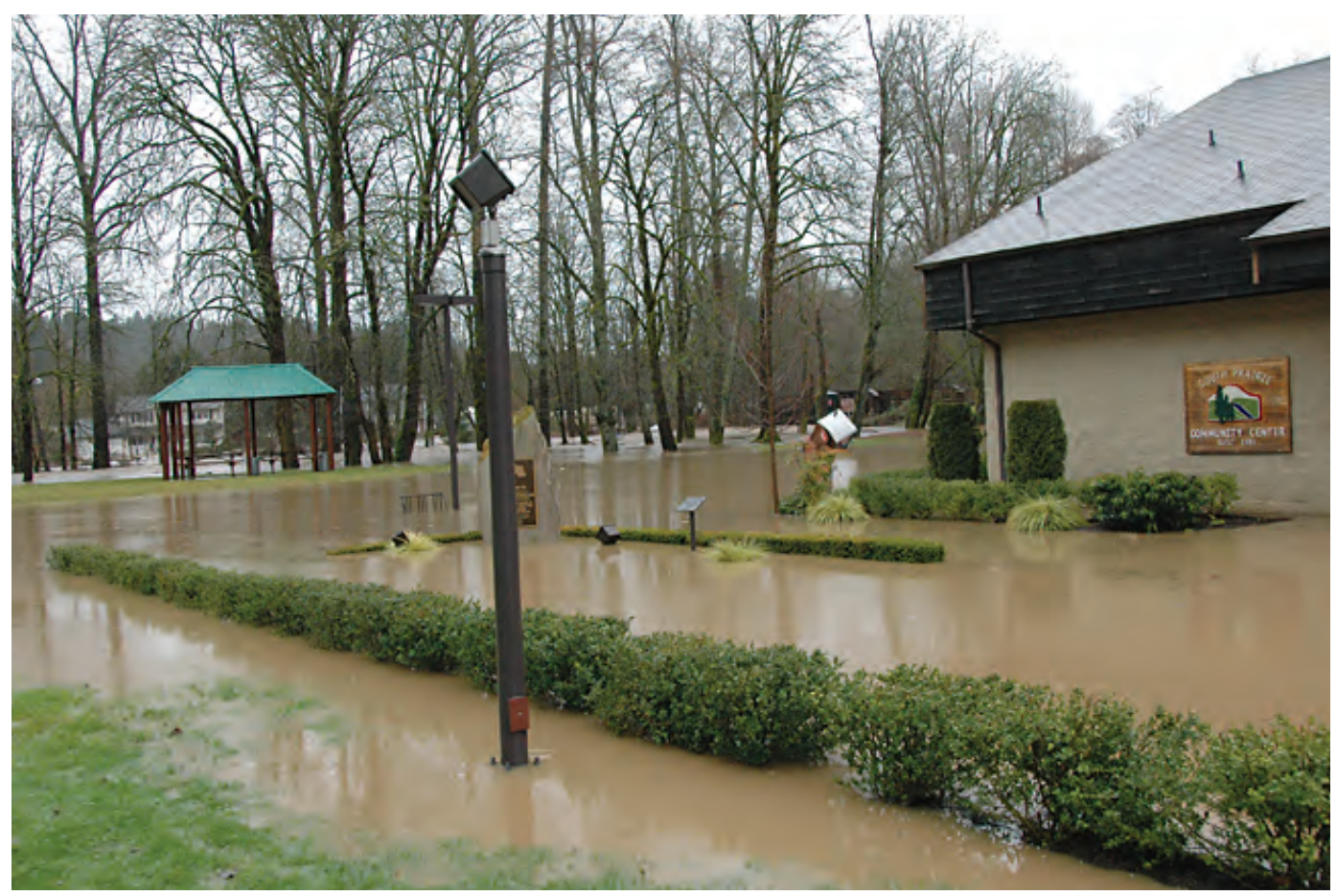

Figure 8. South Prairie Creek, Washington, January 7, 2009, showing flooding of the Community Center and Volunteer Park through a low spot in the grass levee. The U.S. Geological Survey streamflow-gaging station is barely visible behind the fallen portable restroom. Photograph taken by Arlynn Caldwell, private citizen, South Prairie, Washington.

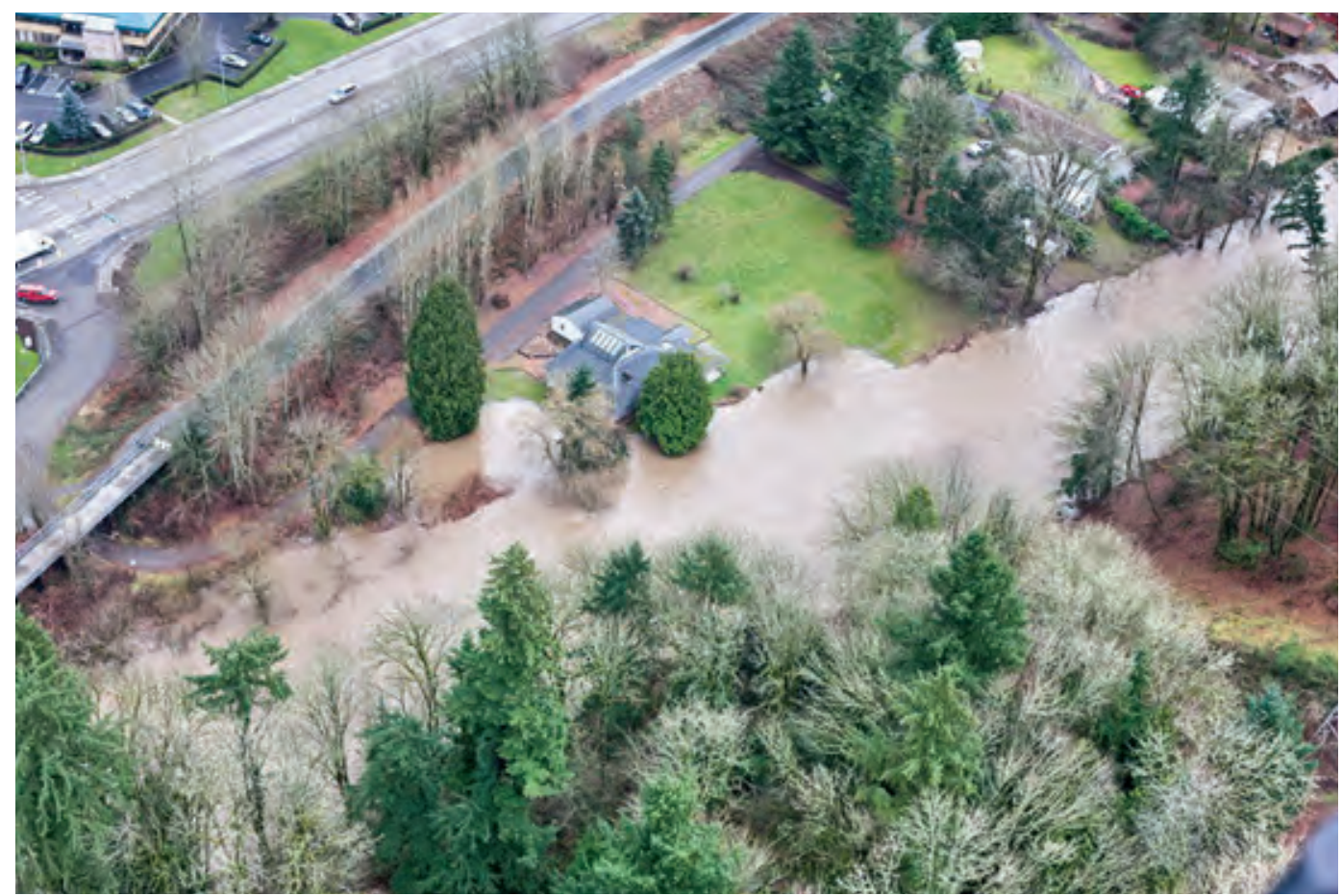

Figure 9. Cedar River near Renton, Washington, near river mile 3, near the upstream end of the study reach. Photograph taken January 9, 2009. Source: King County Flood Photo Viewer, accessed January 2010 at http://www.king county.gov/environment/waterandland/flooding/historical-flood-photos/floodphoto-viewer-map.aspx. 


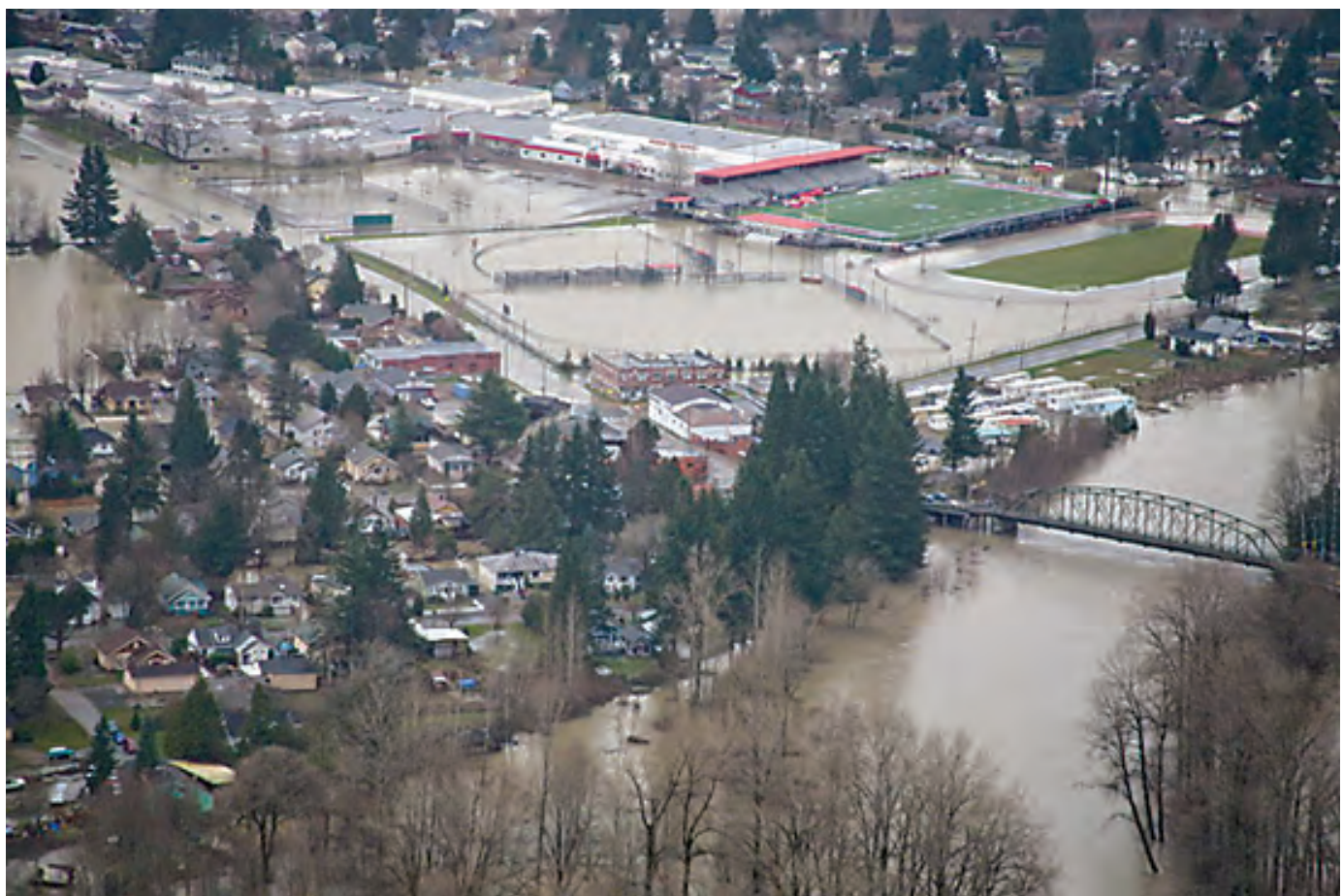

Figure 10. Snoqualmie River at Snoqualmie, Washington, looking downstream just upstream of river mile 42 on January 9, 2009. Snoqualmie High School is in the upper-center of the photograph and the Meadowbrook Way Bridge is at right-center. Source: King County Flood Photo Viewer, accessed January 2010 at http://www.kingcounty.gov/environment/waterandland/flooding/historical-flood-photos/ flood-photo-viewer-map.aspx.

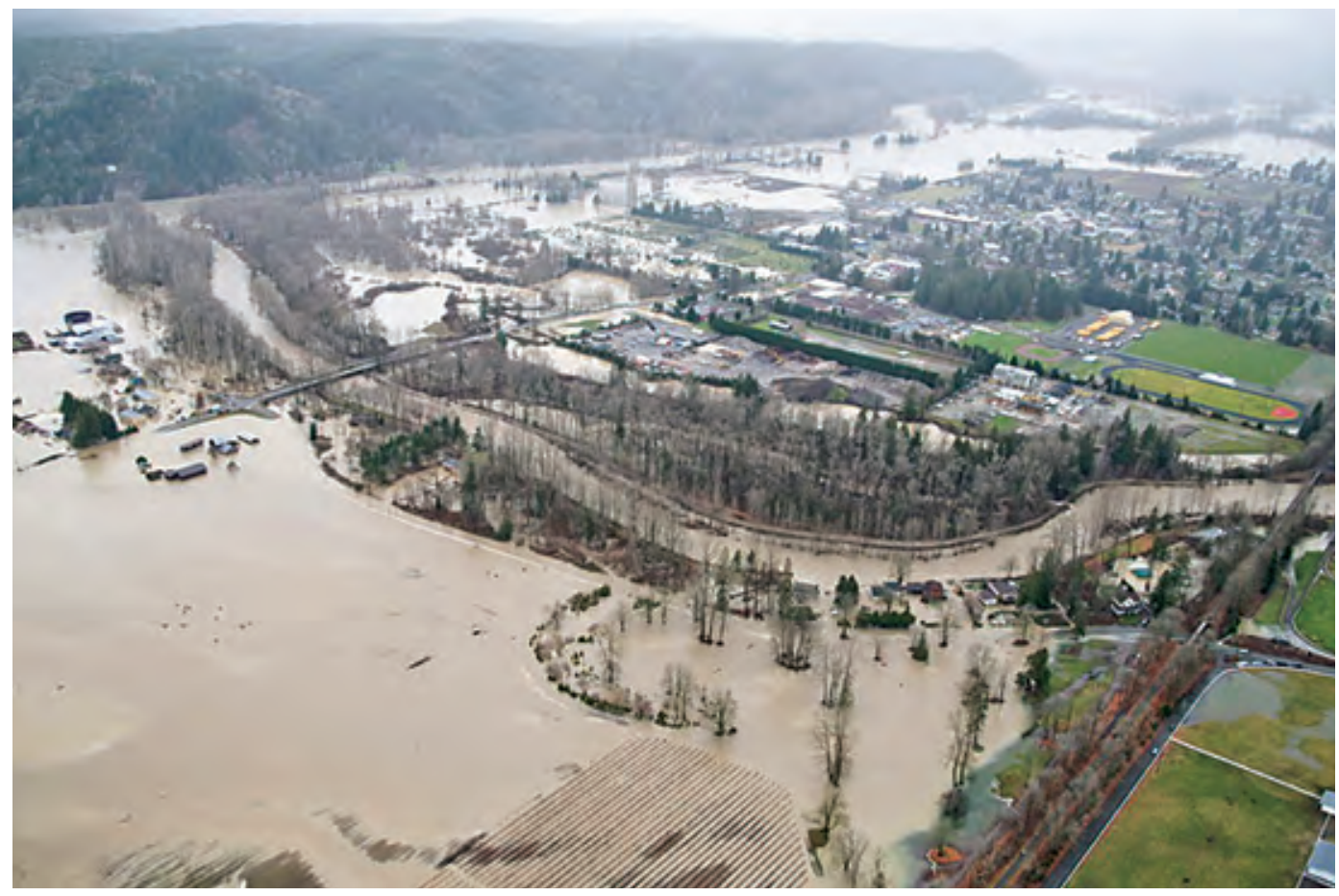

Figure 11. Tolt River (foreground) and the Snoqualmie River at Carnation, Washington, on January 9,2009 . The confluence of the two rivers is at the upper left and the downtown area of the City of Snoqualmie is in the upper right. Source: King County Flood Photo Viewer, accessed January 2010 at http://www.kingcounty.gov/environment/waterandland/flooding/historical-flood-photos/flood-photoviewer-map.aspx. 


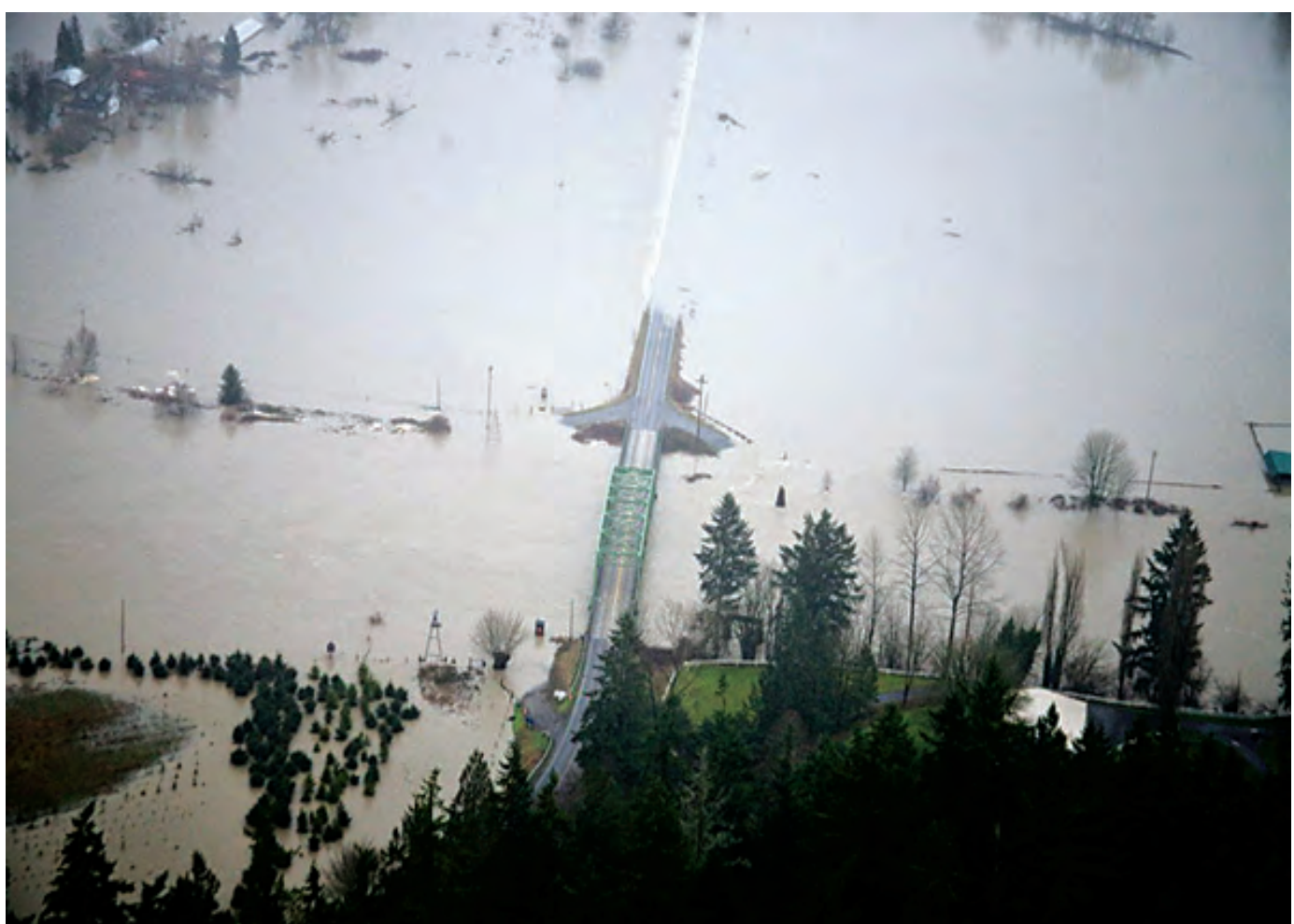

Figure 12. Snoqualmie River near Carnation, Washington, on January 9, 2009, looking eastward from the left bank to the right bank at partially submerged NE Carnation Farm Road at the end of the study reach. The gage house and cableway A-frame of the U.S. Geological Survey streamflow-gaging station, Snoqualmie River near Snoqualmie (12149000) are visible on the left bank, downstream side of the bridge. Source: King County Flood Photo Viewer, accessed January 2010 at http://www.kingcounty.gov/ environment/waterandland/flooding/historical-flood-photos/flood-photo-viewer-map.aspx.

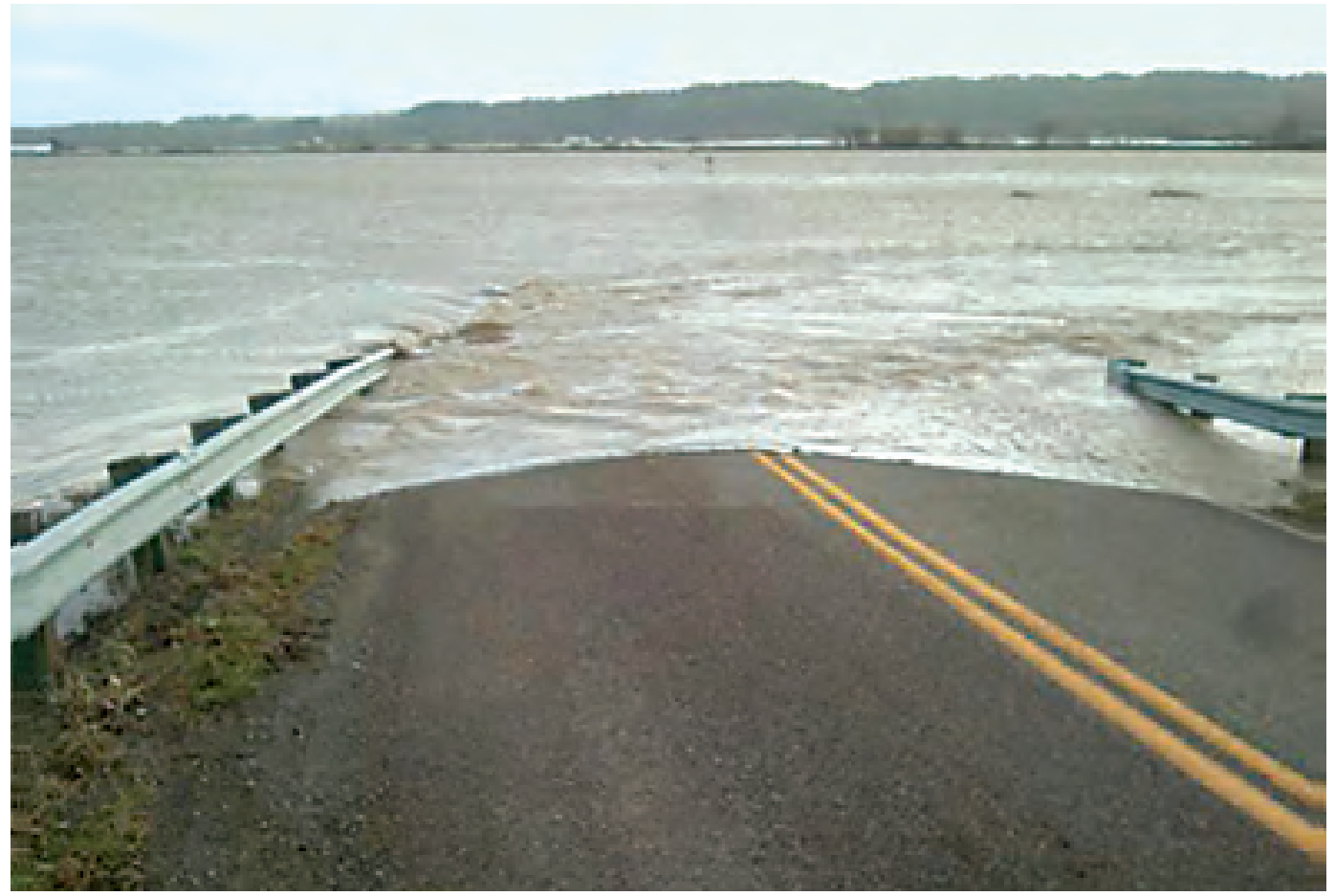

Figure 13. Stillaguamish River Valley, Washington, during the January 2009 flood (exact date unknown). Source: Washington State Department of Transportation, used with permission. 
An estimate of the annual exceedance probability (AEP) of a peak discharge from an annual time series of peak discharges is often used to characterizes the magnitude of a flood. AEP is the inverse of the "return period" or "recurrence interval." For example, an annual peak flow with an AEP of 0.02 or 2 percent, is equivalent to a 50 -year return period or simply the "50-year flood." A flood of this magnitude has a statistical probability of being equaled or exceeded two times in 100 years on average or a 2-percent chance of being equaled or exceeded in any 1 year. In the case of an unusually large flood and a relatively short record of annual peak discharges, the large peak may bias the results of the analysis of those discharges. This is the case in the analysis of flooding in western Washington in January 2009, and opinions differ on how this situation should be handled (Timothy Cohn, U.S. Geological Survey, written commun, 2010). One method is to exclude the unusually large peak discharge in the statistical analysis and then compare the peak discharge to the various flood quantiles estimated for the standard AEPs. This provides a more unbiased method for comparison with the station's probability distribution of annual peak discharges. The other method is to include the unusually large peak discharge in the statistical analysis, which will have the effect of increasing the flood quantiles for a given AEP and reducing the relative magnitude of the large peak discharge. If any new flood-plain mapping or infrastructure design occurs on the flood-plain, all the available annual peak-flow data are used and the analysis would be similar to this latter method. In light of the difference in treatment of unusually large peak discharge values and differences in how the characterization of the flood may be used, both estimates of the AEP are provide in table 5 .

Following procedures described in Bulletin 17b of the U.S. Water Resources Council (1981), the complete record of annual peak discharges through water year 2008, and again through water year 2009, were analyzed to compute AEPs at the eight representative streamflow-gaging stations for the eight selected stream reaches. This procedure uses the Pearson Type III distribution with log transformation of the peak discharges. No historical period was used in the analysis although some small gaps existed in the systematic record for some stations. The historical period in the Bulletin $17 \mathrm{~b}$ procedure has the effect of extending the number of years of the period of record beyond the number of annual peak discharges used in the analysis. When the length of annual peak flow records are relatively short and two or more independent estimates of flood frequency are available, the weighting of the independent estimates is suggested to improve the final estimate (U.S. Water Resources Council, 1981, appendix 8 of Bulletin 17b). A set of regional regression equations for the State of Washington developed by Sumioka and others (1998) was used to provide a second independent estimate of flood frequency.

Using a recently developed Weighted Independent Estimates (WIE) program (Charles Berenbrock and Timothy Cohn, U.S. Geological Survey, written commun., 2010) that weights the results by the variance of the estimates, weighted estimates of flood frequency were computed (table 5). Frequency plots showing the log Pearson Type III and the WIE distributions of all the available peak discharge data are shown in figures 14-21.

Most of the 24-hour daily precipitation totals in January 2009 only approximate the 10-percent exceedance probability (10-year return period) and most of the peak discharges approximate the less than 1 to 10 percent AEP. These conditions suggest that the duration of the heavy rainfall (approximately 3-4 days), antecedent soil-moisture conditions, and the contribution of low-elevation snowmelt were important factors contributing to the relatively high peak discharges - all less than a 10 percent AEP. The peak discharge of the Cedar River at the study reach is at times affected by regulation of flow at Masonry Dam at Cedar Falls for power production and municipal water supply for the City of Seattle. 


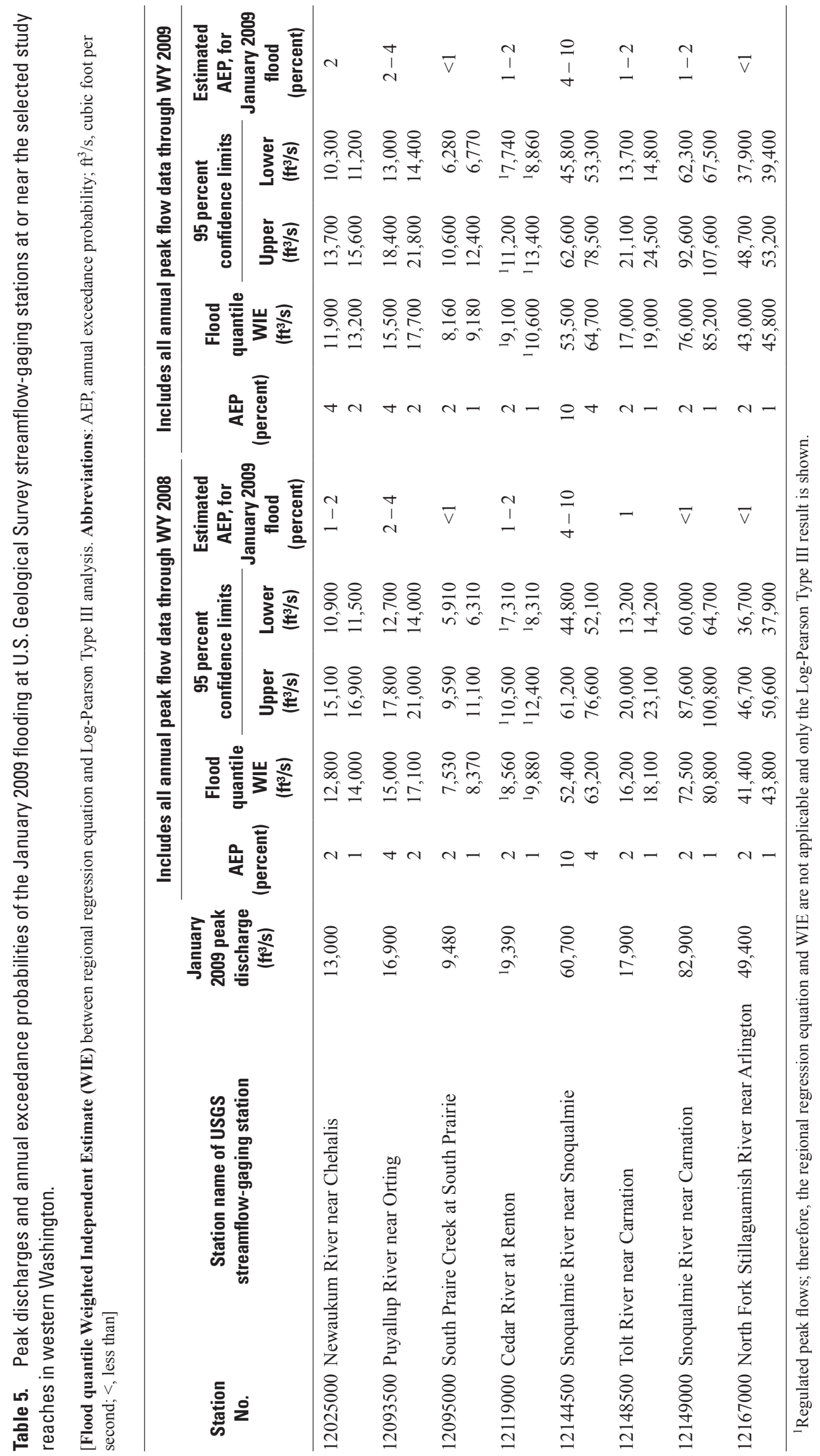




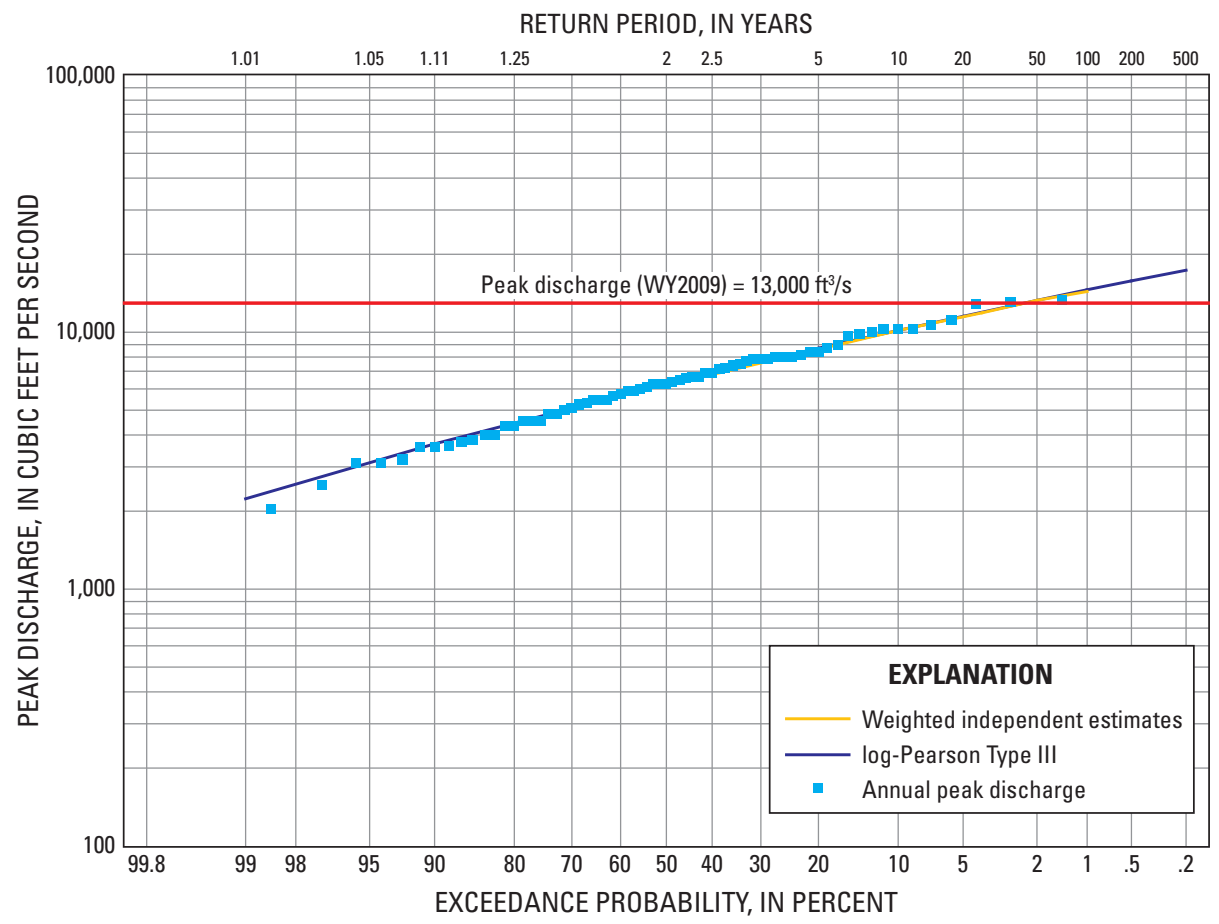

Figure 14. Flood-frequency plot for the Newaukum River near Chehalis, Washington, streamflow-gaging station 12025000, showing the Log-Pearson Type III and weighted independent estimate probability distributions and the annual peak discharges for the period of record through water year 2009.

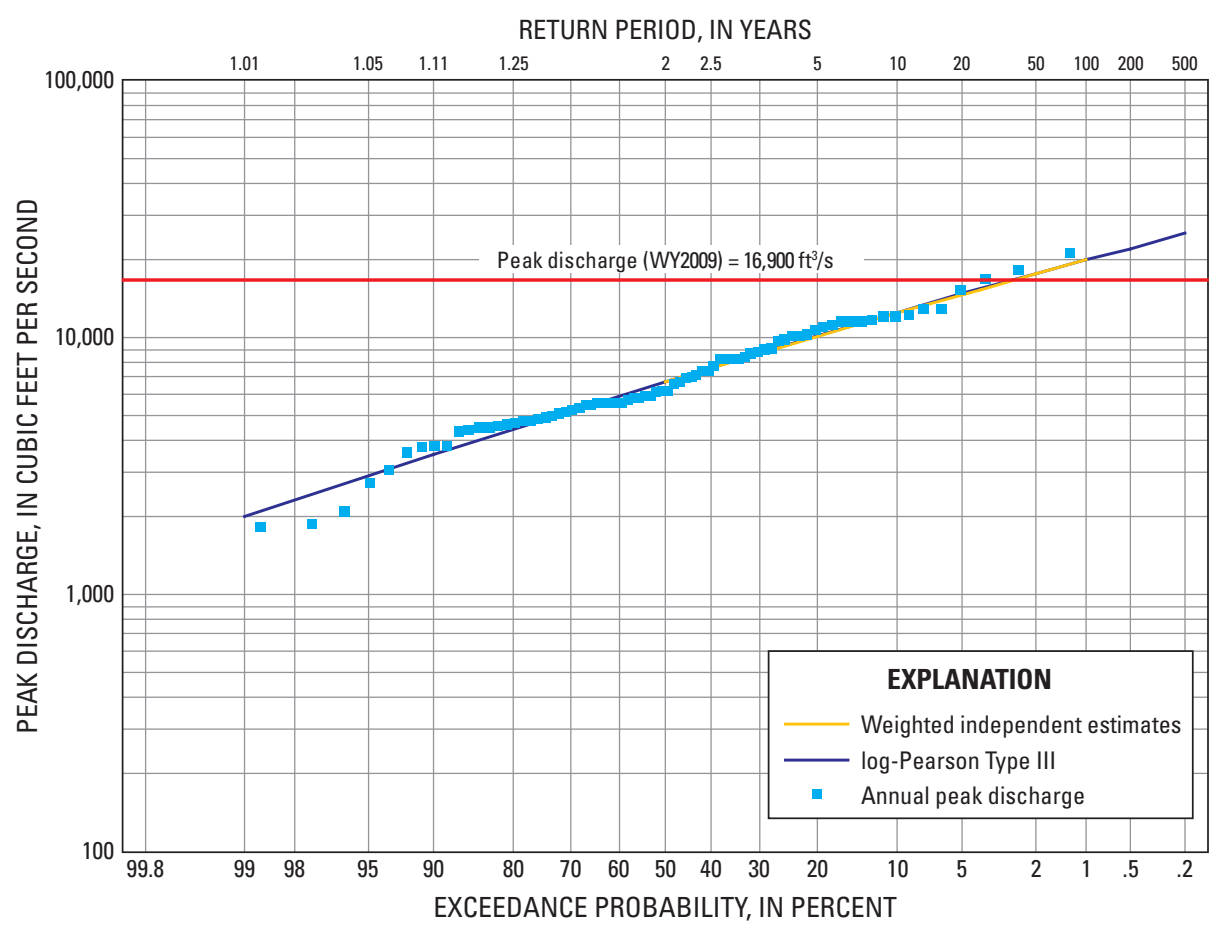

Figure 15. Flood-frequency plot for the Puyallup River near Orting, Washington, streamflow-gaging station 12093500, showing the Log-Pearson Type III and weighted independent estimate probability distributions and the annual peak discharges for the period of record through water year 2009. 
RETURN PERIOD, IN YEARS

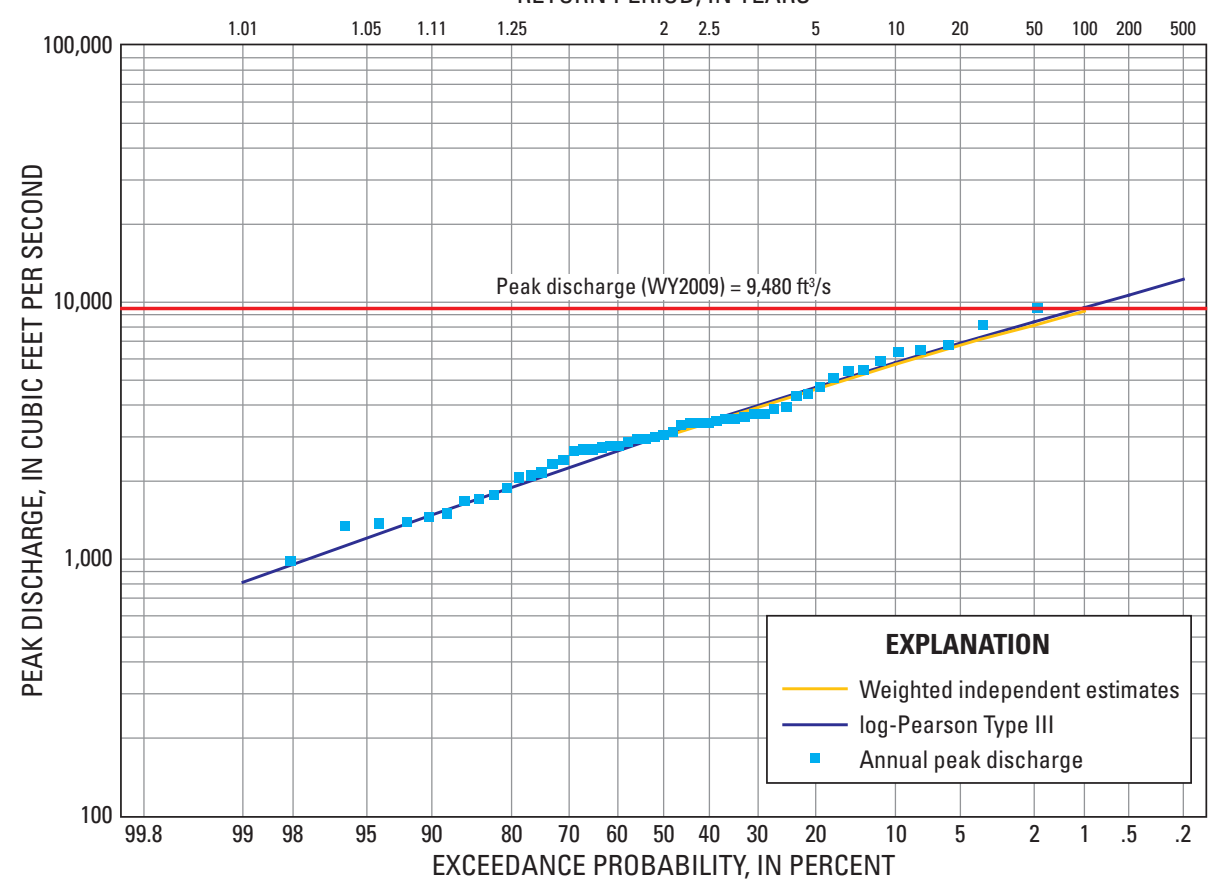

Figure 16. Flood-frequency plot for the South Prairie Creek at South Prairie, Washington, streamflow-gaging station 12095000, showing the Log-Pearson Type III and weighted independent estimate probability distributions and the annual peak discharges for the period of record through water year 2009.

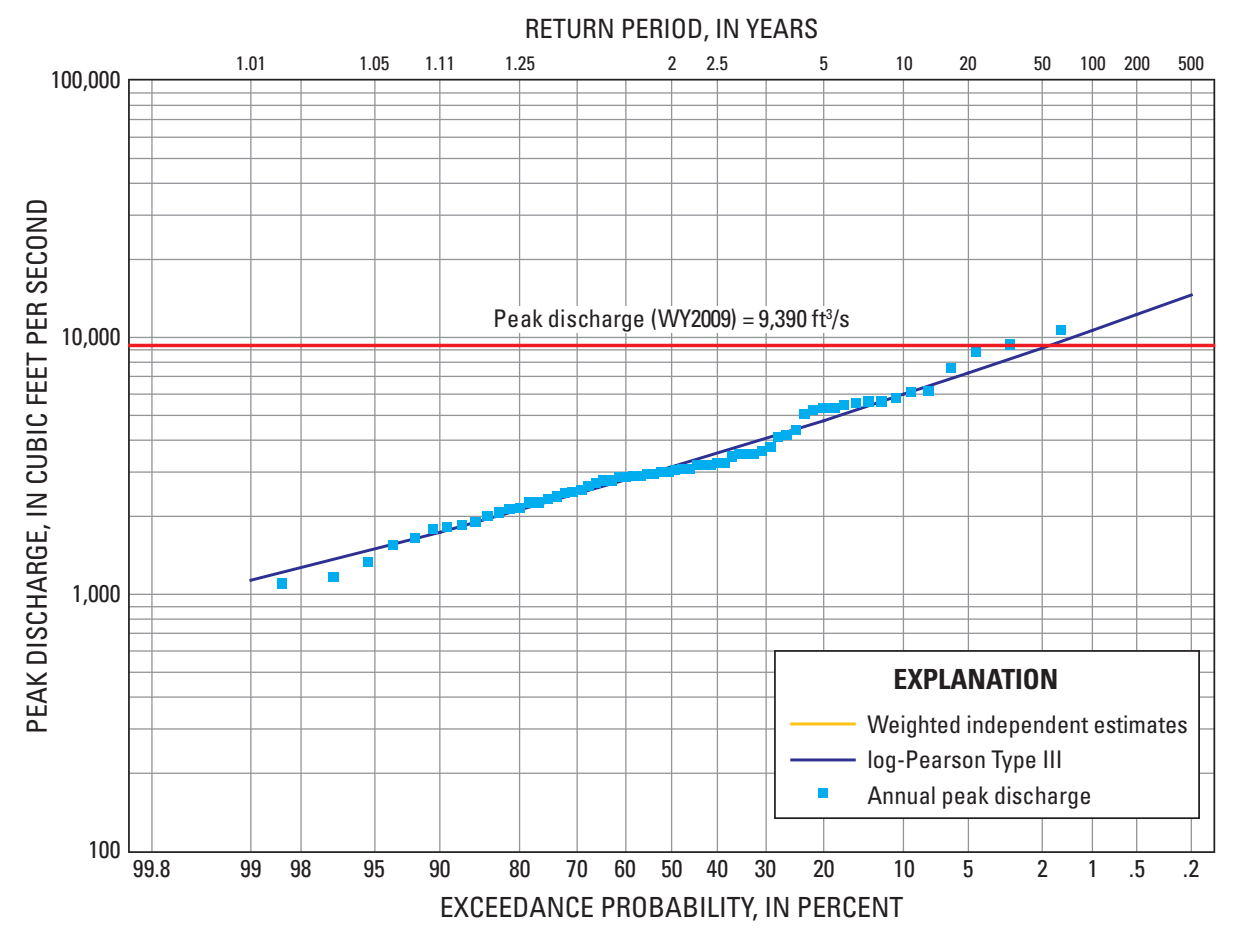

Figure 17. Flood-frequency plot for the Cedar River at Renton, Washington, streamflow-gaging station 12119000, showing the Log-Pearson Type III probability distributions and the annual peak discharges for the period of record through water year 2009. 


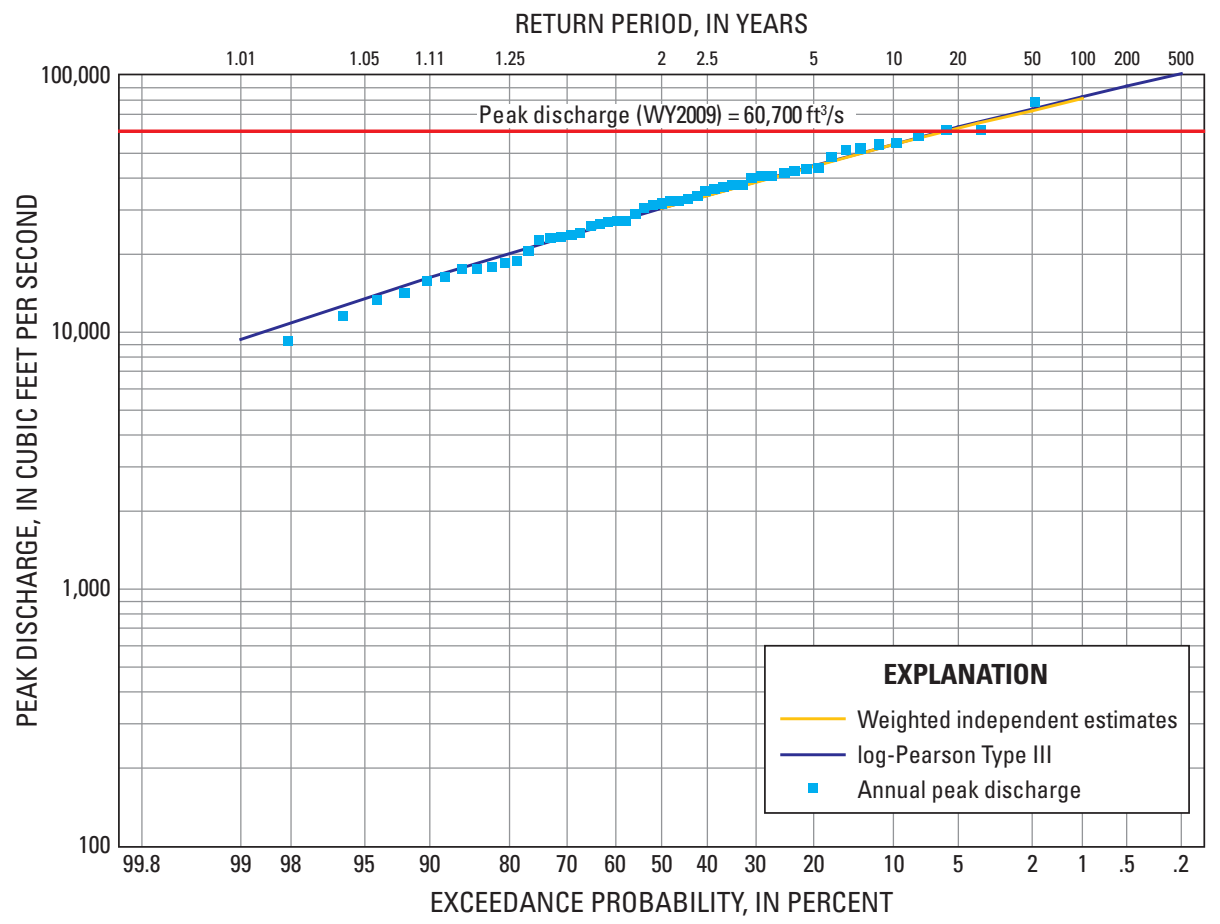

Figure 18. Flood-frequency plot for the Snoqualmie River near Snoqualmie, Washington, streamflow-gaging station 12144500, showing the Log-Pearson Type III and weighted independent estimate probability distributions and the annual peak discharges for the period of record through water year 2009.

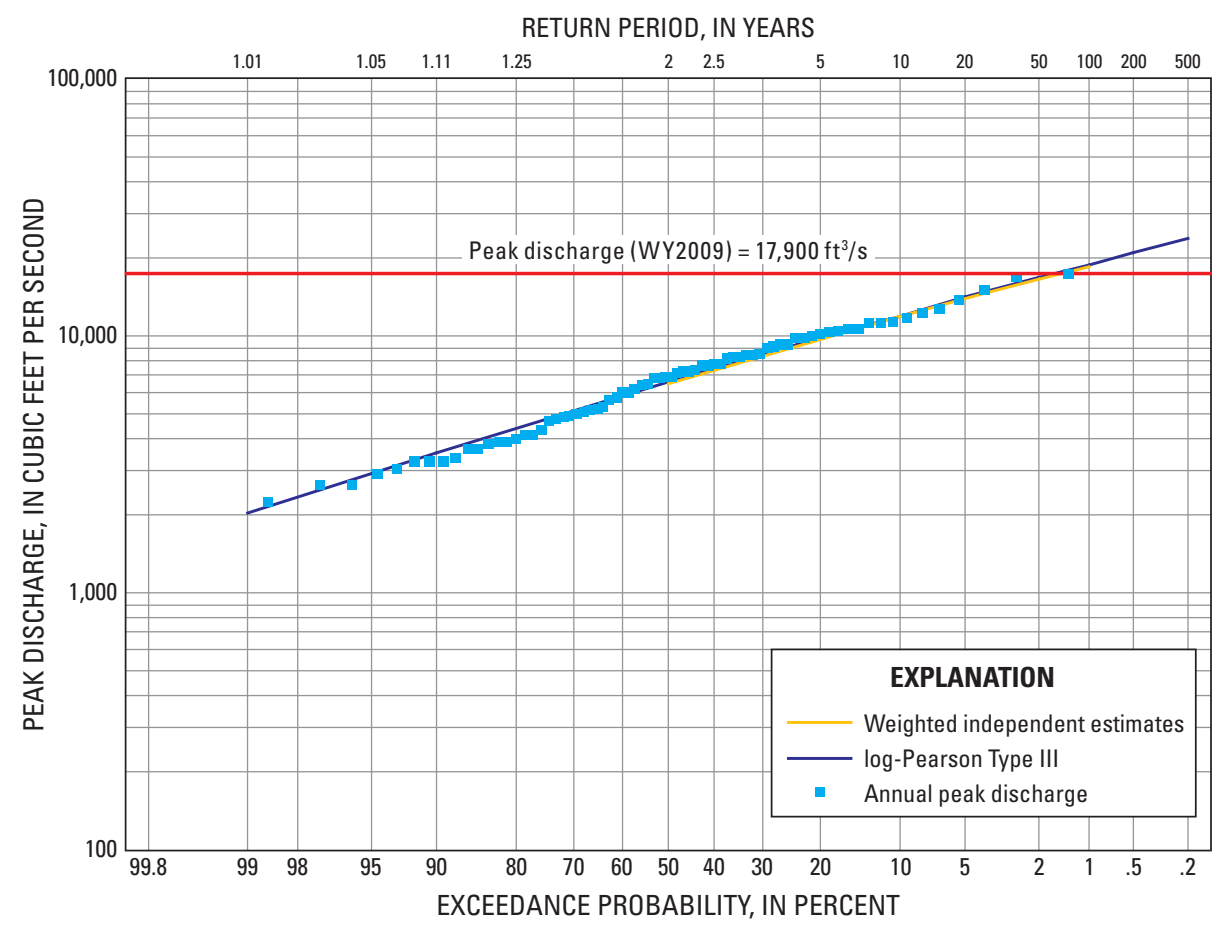

Figure 19. Flood-frequency plot for the Tolt River near Carnation, Washington, streamflow-gaging station 12148500, showing the Log-Pearson Type III and weighted independent estimate probability distributions and the annual peak discharges for the period of record through water year 2009. 
RETURN PERIOD, IN YEARS

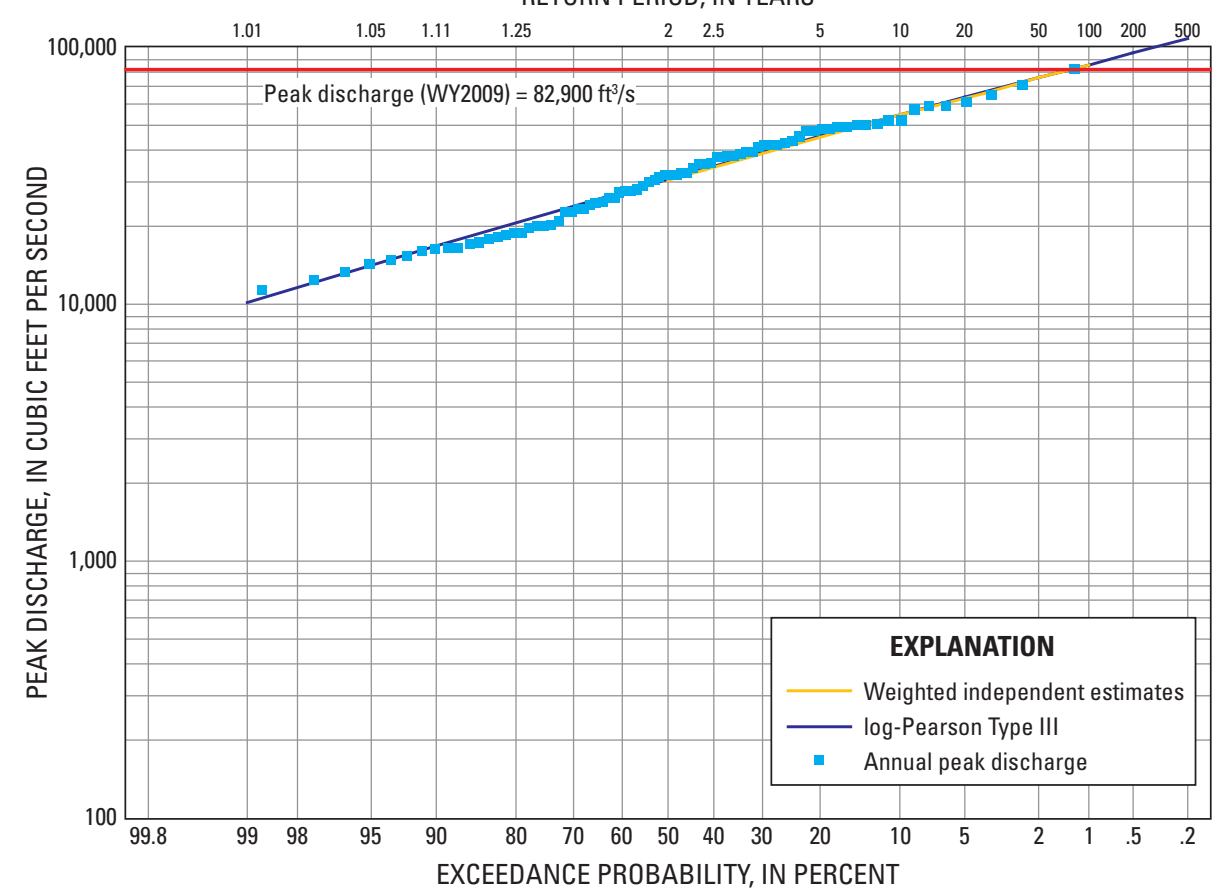

Figure 20. Flood-frequency plot for the Snoqualmie River near Carnation, Washington, streamflow-gaging station 12149000, showing the Log-Pearson Type III and weighted independent estimate probability distributions and the annual peak discharges for the period of record through water year 2009.

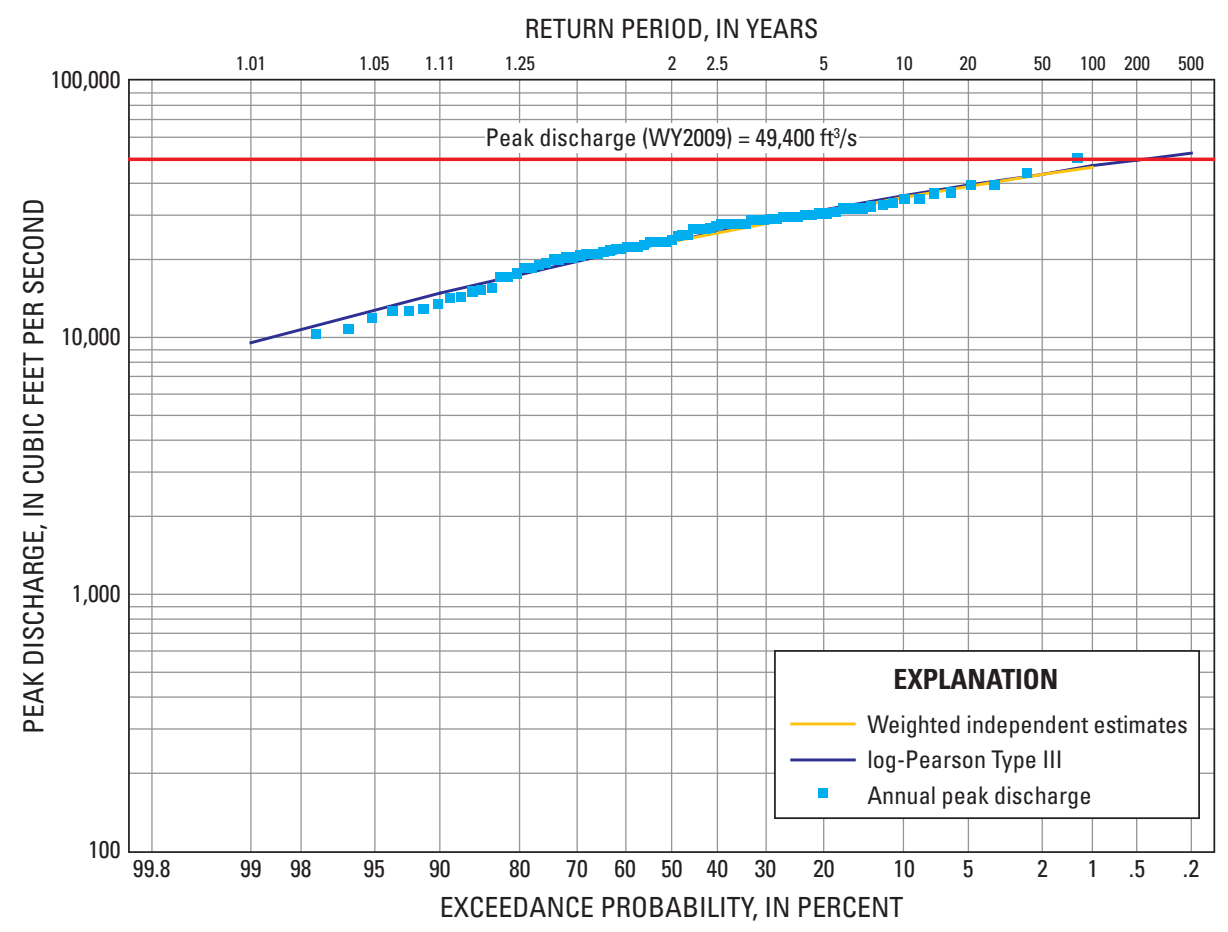

Figure 21. Flood-frequency plot for the North Fork Stillaguamish River near Arlington, Washington, streamflow-gaging station 12167000, showing the LogPearson Type III and weighted independent estimate probability distributions and the annual peak discharges for the period of record through water year 2009. 


\section{Collection of High-Water Mark Data}

The first and most labor-intensive task of this study was the flagging and surveying of high-water marks (HWMs) that indicated the maximum, or peak, water surface during the flood. This information combined with the LiDAR-derived (Light Detection and Ranging) digital-terrain data, provide the essential information for the geographic information system (GIS) analysis used to map the extent and depth of the flood. Although the horizontal locations of the HWMs required accuracies only on the order of tens of feet to be useful for the flood-inundation mapping, the vertical accuracy of the marks was much more critical and needed to be within a few tenths of a foot of their actual elevation to be useful. Due to the required accuracy of the vertical data and the limited time that was available to collect data, a survey-grade Global Positioning System (GPS) and, at times, a total station (survey instrument with electronic angular and distance measurement capabilities) or leveling instrument (level) were used.

The collection of HWM data started on April 9, 2009, 3 months after the flood, and ended in late August of that year. Because HWMs degrade in quality over time, many initially excellent-quality HWMs, such as mud lines on buildings, were lost to rain and property owners cleaning their buildings. For this study, the marks were located and "logged" as quickly as possible by a two-person "flagging" team, and their locations and elevations were subsequently documented by a twoperson "survey" team.

As the HWMs were surveyed, the data were posted on the project's web page (http://wa.water.usgs.gov/projects/

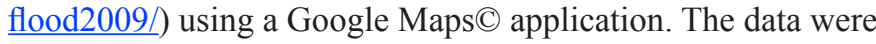
posted on an interactive viewer with street, satellite, and (or) terrain maps in the background.

\section{Flagging of High-Water Marks}

At each study reach, a two-person flagging team located HWMs at intervals of approximately $500 \mathrm{ft}$ on each side of the river or creek. Each HWM was described on a field sheet (fig. 22) that included a rating for quality, photograph numbers, an indication whether the mark was flagged with orange flagging tape and (or) a plastic 1-in. round marker (fig. 23), a preliminary latitude and longitude of the HWM as indicated by a hand-held GPS, and directions to the mark. The quality rating of a HWM is subjective based on the clarity of the mark and a comparison to nearby HWMs, following the guidelines of Lumia and others (1987; table 6) to indicate how accurately the HWM defined the peak water-surface elevation of the flood. Flagged HWMs included mud lines on structures, debris lines, or debris piles along banks and in vegetation, and tree scars.

\section{High Water Mark}

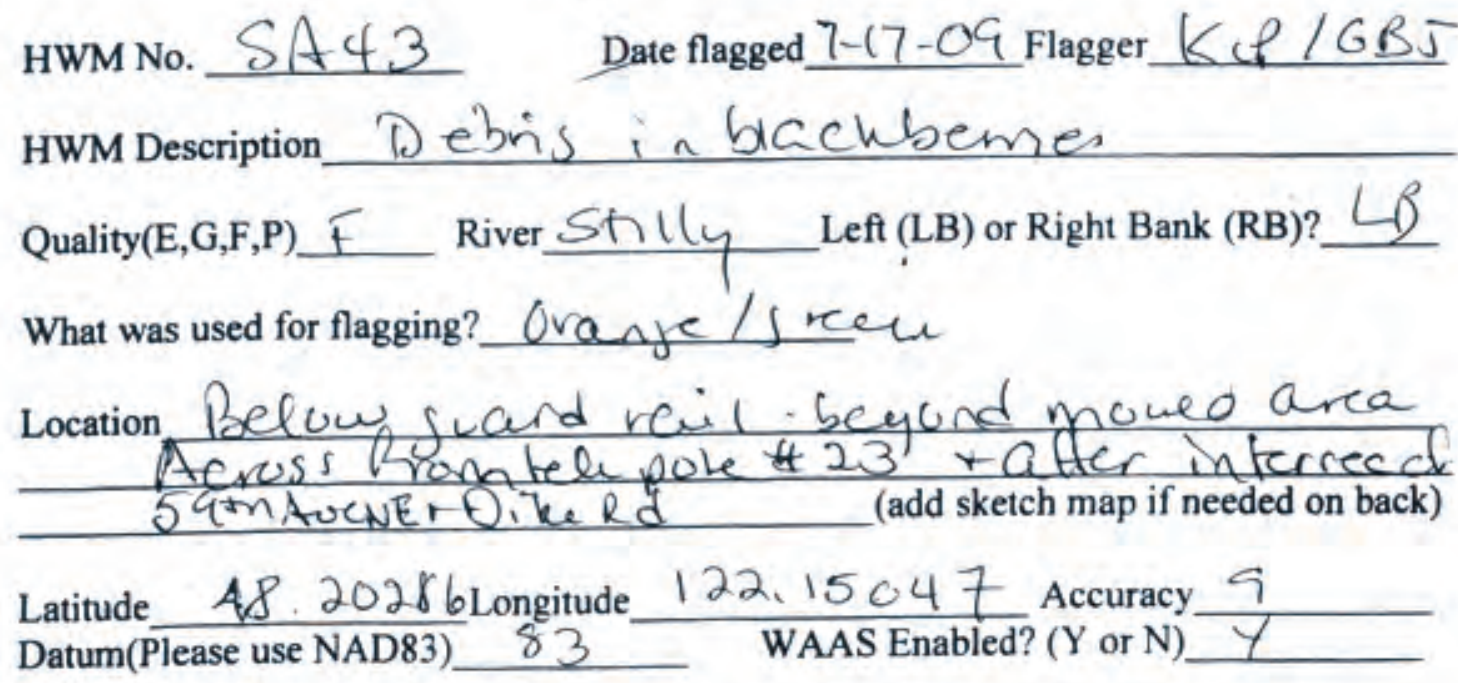

Photos (photo numbers) $8107810 \gamma$ Able to survey with GPS? $\frac{Y}{\text { Initials }}$
EM

Figure 22. Field sheet completed by the flagging team for high-water mark SA43 on the Stillaguamish River, Washington. 


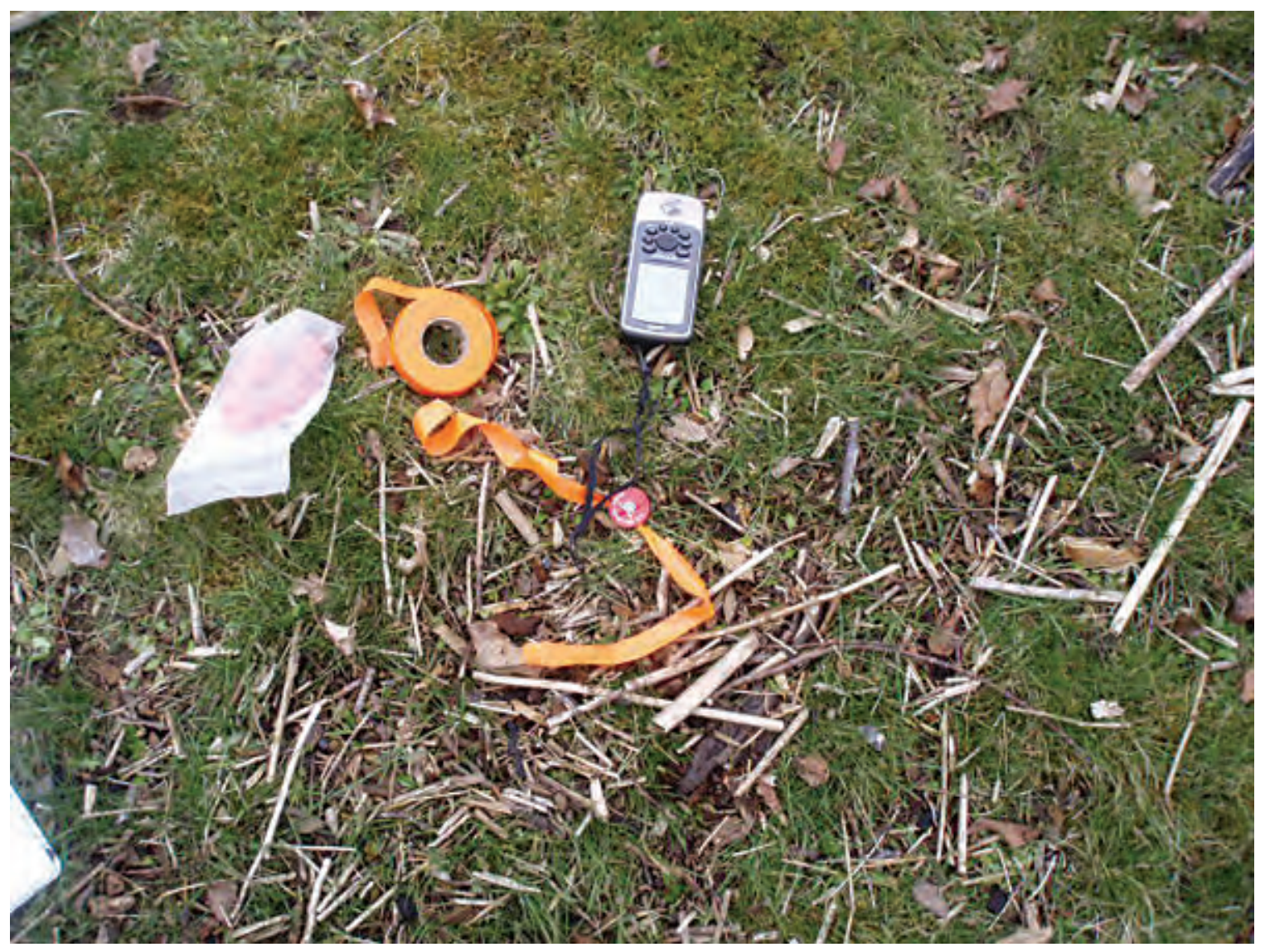

Figure 23. High-water mark (HWM) SP1 in Veterans Park on the left bank of South Prairie Creek at South Prairie, Washington, showing some of the flagging team tools-orange flagging tape, plastic 1-inch round marker, and a hand-held GPS unit. This HWM was described as a good quality, small debris line. (Photograph taken by Mark Mastin, U.S. Geological Survey, March 3, 2009.)

Table 6. High-water mark ratings.

\begin{tabular}{lc}
\hline \multicolumn{1}{c}{ Rating } & $\begin{array}{c}\text { Accuracy } \\
\text { (feet) }\end{array}$ \\
\hline Excellent (Ex) & \pm 0.02 \\
Good (G) & \pm 0.05 \\
Fair (F) & \pm 0.10 \\
Poor (P) & Greater than \pm 0.10 \\
\hline
\end{tabular}




\section{Survey of High-Water Marks}

Following the flagging team, the survey team surveyed the flagged HWMs and often included a survey of nearby HWMs for verification of the flagged marks.

\section{Instrumentation}

A Real-Time Kinematic (RTK) GPS unit was used to survey the position and elevation of most of the HWMs. Trimble $\mathbb{R}$ R8 receivers with Trimble ${ }^{\circledR}$ TSC2 controllers that contained the operating software and logged the data were used to collect the data (fig. 24). The R8 GPS units receive the GLONASS (GLObal Navigation Satellite System) satellite data (Russian constellation of satellites) as well as data from the United States GPS satellites; therefore, the number of satellites in view in an unobstructed horizon was never a limiting factor in the ability to obtain a GPS position for a HWM. In areas where dense tree cover interfered significantly with the GPS satellite signal, a survey level or total station was used to survey the HWM. The RTK GPS, however, established the starting reference marks for the level or totalstation survey.

The manufacturer of the RTK GPS reported a root mean square (RMS) accuracy for the vertical dimension is $\pm 2 \mathrm{~cm}$ plus 1 part per million $(\mathrm{ppm}) \times$ baseline length. Typically, with a base radio and rover setup, baselines were limited by the distance of the radio broadcast that was generally about $5 \mathrm{mi}$ or a baseline of $52,800 \mathrm{ft}(5 \times 5,280 \times 2)$. By the manufacturer's guidelines, a baseline of this length would result in a potential vertical, 1 -sigma error of $0.118 \mathrm{ft}$ relative to the monument that is being used. The reported horizontal accuracy is $\pm 1 \mathrm{~cm}$ plus $1 \mathrm{ppm} x$ baseline length. For the same long baseline described above, the 1-sigma error would be $0.086 \mathrm{ft}$ relative to the monument.

\section{Survey Procedure}

Two techniques for RTK GPS surveying were used to collect HWM elevations for this study. The traditional RTK GPS technique uses a base GPS on a known survey monument (base) that receives GPS signals, computes a positional error, and then broadcasts the error via radio. A second GPS receiver (rover) receives the GPS signals and the broadcast positional errors from the base receiver and computes a corrected position for each HWM. A second RTK GPS survey technique sometimes referred to as RTN (Real-Time Network; Shrock, 2006) utilizes a network of continuously operating GPS stations known as the Washington State Reference Network (WSRN) that provides real-time correction to the rover GPS via a cellular data connection, thus eliminating the need for a base station. WSRN is a regional cooperative organized by Seattle Public Utilities, which housed the central processing computers (for more information see http://www.wsrncontent. org/prsn/). The study reaches on South Prairie Creek, Puyallup River, Snoqualmie River at Snoqualmie, and the

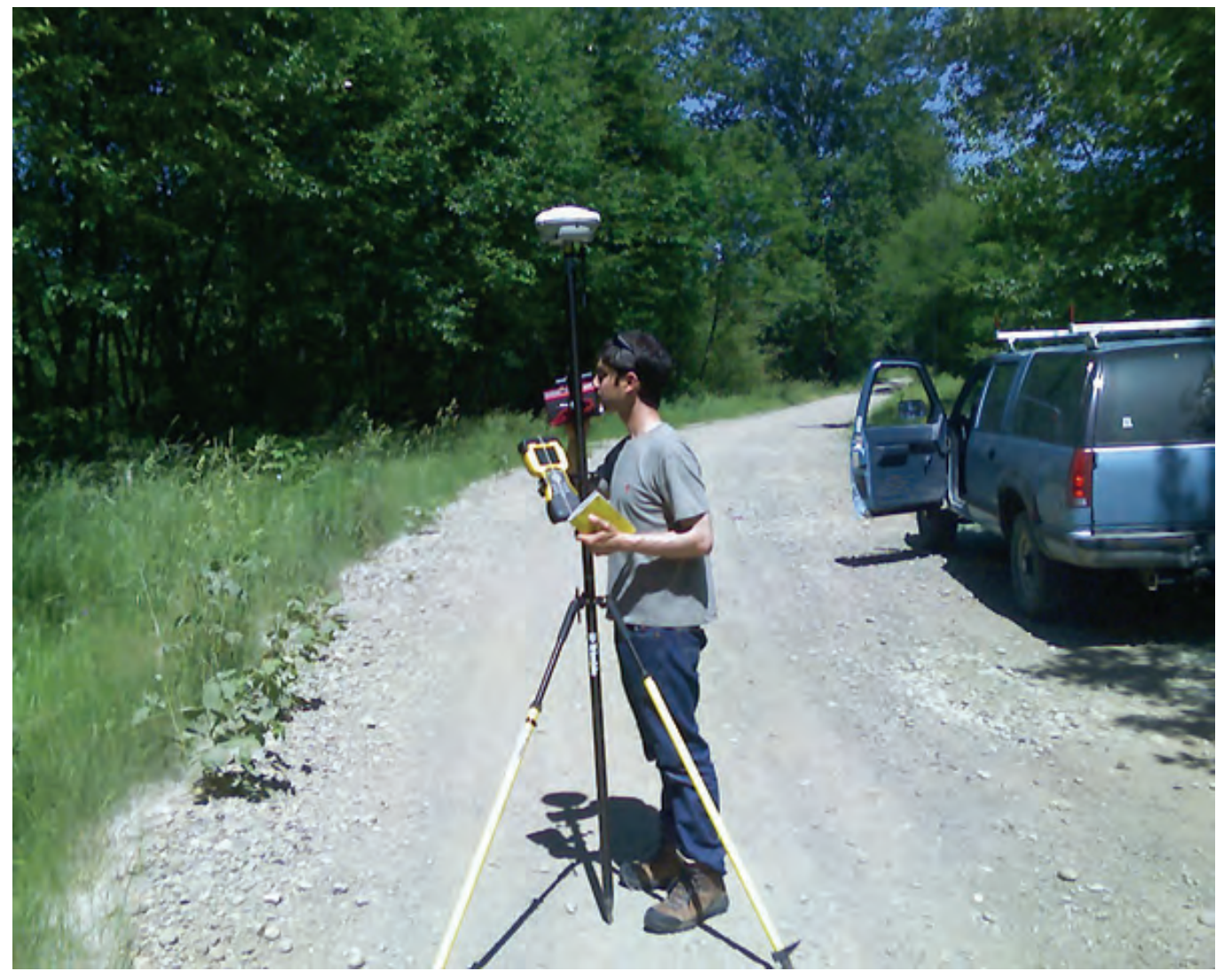

Figure 24. U.S. Geological Survey hydrologist demonstrating the use of a pole-mounted laser range finder with angle encoder to compute the vertical offset from the high-water mark (not visible in the photograph) to the laser range finder mount point on the global positioning system (GPS) unit pole. Also shown in the photograph is the 2.0 meter black GPS pole, GPS R8 receiver on top of the pole, GPS bipod that supports the pole, and the TSC2 data collector mounted on the pole below the range finder. Photograph taken by Mark Mastin, U.S. Geological Survey, June 3, 2009. 
Tolt River reaches were surveyed using the traditional RTK GPS technique. Study reaches on the Snoqualmie River at Carnation, Cedar River, Newaukum River, and Stillaguamish River were surveyed using the RTN technique. There was no indication of any loss of accuracy because of the use of the RTN technique (table 7).

To verify GPS accuracy, a local survey monument with known coordinates was checked at the beginning and end of each survey day. All survey monuments used were part of the Washington State Department of Transportation (WSDOT) Survey Monument Database (available online at: $\underline{\mathrm{http}: / /}$ www.wsdot.wa.gov/monument/). The reported accuracy of the orthometric height generally was $1 \mathrm{~cm}(0.033 \mathrm{ft})$, although some reported accuracies were as high as $5 \mathrm{~cm}$ $(0.164 \mathrm{ft}$, table 7$)$. The survey at each study reach was set to the coordinate system used to report the coordinates of nearby WSDOT survey monuments. The surveys at South Prairie Creek, Puyallup River, and Newaukum River all used the Washington State Plane South coordinate system, and the other reaches used the Washington State Plane North coordinate system. All horizontal and vertical coordinates were converted to U.S. survey feet. The horizontal datum NAD 83 and vertical datum NAVD 88 were used. GEOID03 was the geoid model used to convert ellipsoid heights to orthometric heights above sea level.

At many HWMs, a direct GPS survey could not be obtained on the mark due to excessive tree cover or proximity to buildings. If there was a nearby (within $50 \mathrm{ft}$ ) location where an accurate GPS location within sightline of the HWM could be obtained, a pole-mounted laser range finder with an angle encoder was used to take a reading on the HWM. A target with a reflector (fig. 25) would be set in line with the HWM and the pole-mounted laser from the remote location would be used to determine the vertical height difference from the measured angle and distance. Using this vertical offset plus the measured distance from the laser range finder to the bottom of the antenna, a revised GPS antenna height was computed before collecting the satellite data (fig. 24). The reported vertical-angle accuracy of the laser range finder is plus or minus 0.1 degrees. At a distance of $50 \mathrm{ft}$, this would equate to a vertical error of $\pm 0.087 \mathrm{ft}$. When this method was used the standard procedure was to minimize the distance away from the HWM, use the filtering option on the laser range finder, stay within $50 \mathrm{ft}$ of the HWM, and compute the average vertical offset from three or more readings. Usually, no correction for horizontal position was made.

Table 7. Vertical error at global positioning system survey checks at Washington State Department of Transportation survey monuments made during the high-water mark survey at the eight selected stream reaches in western Washington.

[Abbreviations: WSDOT, Washington State Department of Transportation; SPS, Washington State Plane South coordinate system (zone 5626); SPN, Washington State Plane North coordinate system (zone 5601); GPS, Global Positioning System; cm, centimeter; ft, foot]

\begin{tabular}{|c|c|c|c|c|c|c|c|}
\hline Stream reach & $\begin{array}{c}\text { WSDOT } \\
\text { monument } \\
\text { identifier }\end{array}$ & $\begin{array}{l}\text { Horizontal } \\
\text { coordinate } \\
\text { system } \\
\text { used }\end{array}$ & $\begin{array}{l}\text { Reported } \\
\text { orthometric } \\
\text { height } \\
\text { accuracy } \\
\text { (cm) }\end{array}$ & $\begin{array}{c}\text { Number of } \\
\text { survey } \\
\text { checks }\end{array}$ & $\begin{array}{c}\text { Average } \\
\text { error } \\
\text { (ft) }\end{array}$ & $\begin{array}{c}\text { Maximum } \\
\text { error } \\
\text { (ft) }\end{array}$ & $\begin{array}{c}\text { Average } \\
\text { absolute } \\
\text { error } \\
\text { (ft) }\end{array}$ \\
\hline \multirow[t]{2}{*}{ Puyallup River } & 3853 & SPS & 1 & 1 & 0.049 & 0.049 & 0.049 \\
\hline & 6390 & SPS & 1 & 4 & .062 & .099 & .062 \\
\hline \multirow[t]{2}{*}{ South Prairie Creek } & 6396 & SPS & 1 & 3 & -.088 & -.102 & .088 \\
\hline & 6397 & SPS & 1 & 5 & .074 & .109 & .074 \\
\hline \multirow[t]{2}{*}{ Snoqualmie River near Snoqualmie } & 5402 & SPN & 1 & 5 & .041 & .069 & .041 \\
\hline & 5092 & SPN & 5 & 4 & .048 & .197 & .080 \\
\hline Snoqualmie and Tolt Rivers near Carnation & 2445 & SPN & 1 & 4 & -.063 & -.153 & .065 \\
\hline \multirow[t]{2}{*}{ Newaukum River } & 6782 & SPS & 5 & 24 & -.080 & .158 & .083 \\
\hline & 6785 & SPS & 1 & 4 & -.107 & -.153 & .107 \\
\hline Stillaguamish River & 8 & SPN & 1 & 16 & -.004 & .053 & .015 \\
\hline All GPS checks & & & & 108 & -.023 & .197 & .061 \\
\hline
\end{tabular}




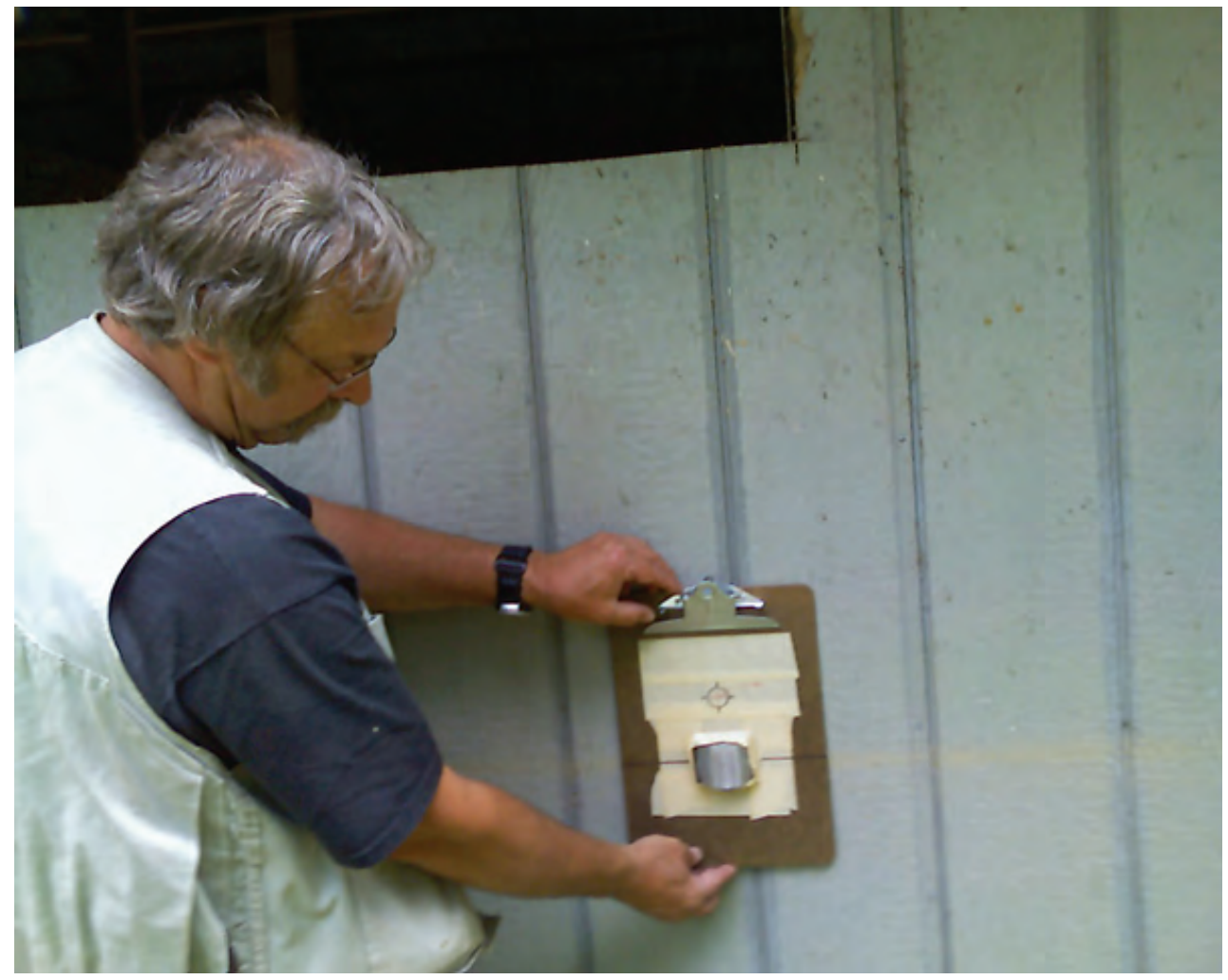

Figure 25. U.S. Geological Survey hydrologist lining up (horizontal black line) a home-made reflector on a mud line high-water mark (faint, light brown line on siding) to be surveyed remotely by an RTK GPS unit and a pole-mounted laser range finder. The laser range finder is aimed at the small circle above the reflector to compensate for the vertical offset of the aiming scope and the laser. Photograph taken by Andrew Gendaszek, U.S. Geological Survey, June 18, 2009.
A rigorous assessment of the vertical error for each HWM would be difficult to make considering the conditions in the field. However, a rough assessment could be made. Considering the vertical errors in the survey checks in table 7 as the GPS survey error of HWMs under optimal conditions, the standard error is about $0.073 \mathrm{ft}$ or a 2-sigma error of $0.15 \mathrm{ft}$. As mentioned above, additional vertical error may have been introduced when the pole-mounted laser range finder, level or total station were used or when the canopy cover reduced the number of satellites visible to the GPS unit. These factors might add an additional $0.1 \mathrm{ft}$ to the vertical error. When the vertical error in the identification of the HWM, which was assumed to range from 0.02 to 0.10 $\mathrm{ft}$ (Excellent to Fair marks, see table 6), is considered then the range in error associated with HWMs would be $0.17 \mathrm{ft}$ (2-sigma) under ideal surveying conditions and $0.35 \mathrm{ft}$ for fair HWMs under poor surveying conditions.

\section{Creating Web-Based, High-Water Mark Maps}

After the HWMs were surveyed, the horizontal coordinates were converted to geographic coordinates, based on NAD 83. An Excel file of all HWMs was compiled and made available on the project web site (http://wa.water.usgs. gov/projects/flood2009/). Associated with each HWM was an identification code, quality code, and the surveyed elevation, above NAVD 88. A set of seven interactive Google Maps ( applications were developed for the project web site. (The Snoqualmie River at Carnation and Tolt River reaches are combined due to their proximity.) The applications provide the HWM locations on a street-map, satellite, and (or) terrain base map that allows the user to define and change the extent of the map and view the associated data with a simple click over the HWM of interest. The Google Map(C) applications can be found for the eight reaches at: http://wa.water.usgs.gov/ projects/flood2009/data.htm (see figures 26-27 for examples). 

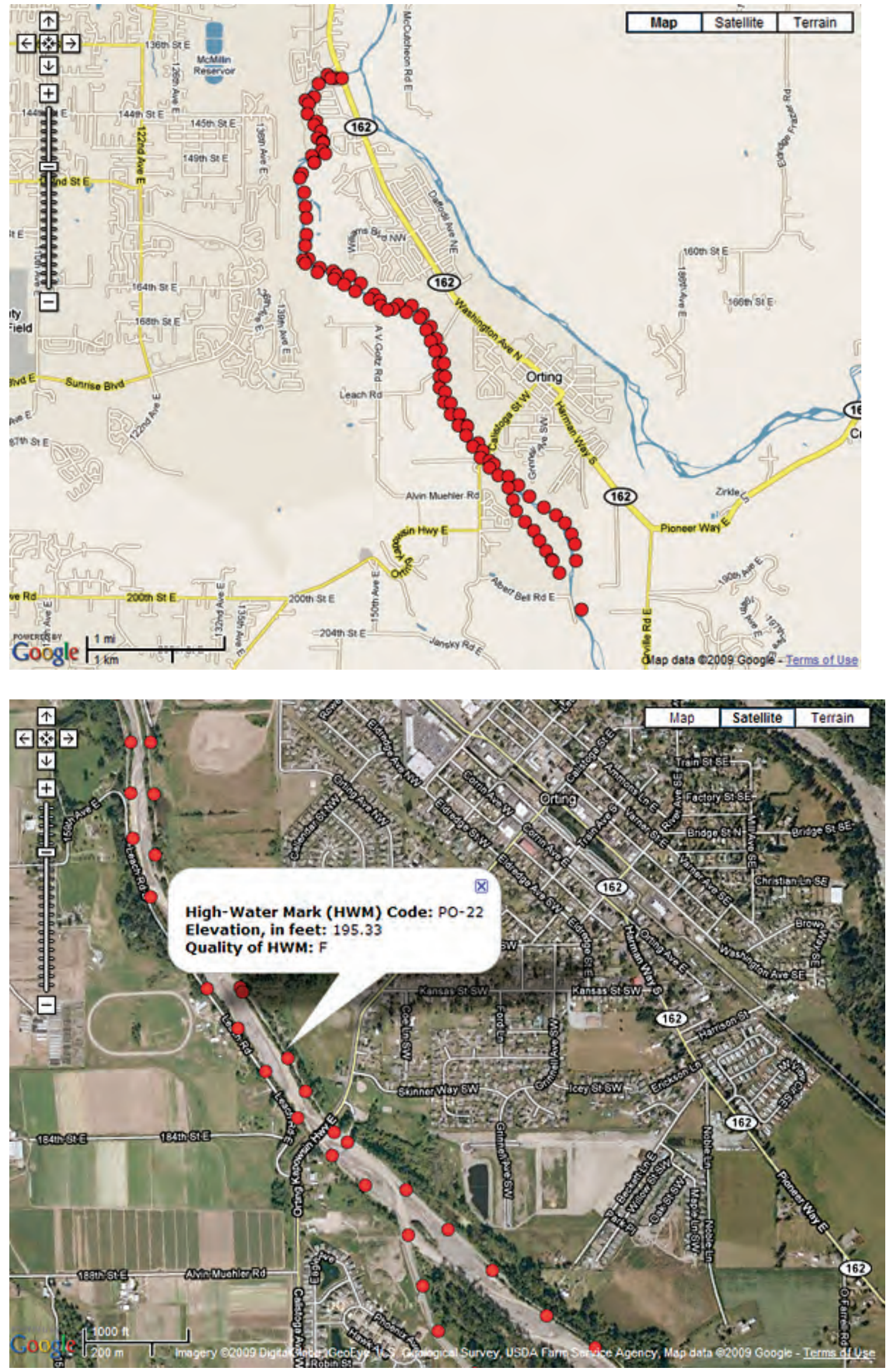

Figure 26. Locations of all surveyed highwater marks in the Puyallup River near Orting, Washington, study reach in an interactive Google Maps application.
Figure 27. The

Puyallup River near Orting, Washington, study reach showing some of the surveyed high-water marks in an interactive Google Maps application and the attributes of individual high-water mark P0-22. 


\section{Flood Inundation Maps}

Flood inundation maps show the extent and depth of the peak flooding. The HWMs defined only the elevation of the peak water surface at one point in the flood profile, and generally, the marks were not located at the farthest extent of the flood away from the center of the main channel. However, if the floodplain elevation of the stream valley is known at a HWM, the extent of flooding can be estimated by projecting the HWM elevation horizontally and (generally) perpendicular from the direction of flow until it intersects with the land elevation on both sides of the river. Using a number of these horizontally projected lines (labeled on maps as "Potential water-surface contour") that generally are perpendicular to the flood flow direction, a sloping surface that matches the floodwater-surface profile can be constructed to define a two-dimensional water surface at the flood peak. In GIS, this surface can be intersected with a terrain surface (Digital Elevation Model, or DEM) to define the extent of flooding as the areas where the difference of the water-surface elevation minus the terrain elevation is greater than zero. These positive values also equate to the flood depth and where the values are negative, the terrain was not flooded; hence, the word "potential" is used to describe the water-surface contour. The LiDAR-derived DEMs used in this study do not usually capture the river geometry below the water surface at the time the LiDAR data are collected, and therefore, the depths computed in the channel may not be correct. This method of intersecting the water surface with the DEM works well to define the area of inundation for a well-confined river at flood stage using GIS techniques, HWM point coverages, and a high-resolution DEM. When water breaks over a levee or riverbank and the flow becomes disconnected from the main channel, it may assume a different slope than the water in the main channel, and that slope is not immediately tractable by the GIS mapping tool. In such cases, auxiliary HWMs and information gathered from local residents and local agency officials who witnessed the flooding was used to estimate the areas of inundation disconnected from the main channel.

The mapping procedure used a set of GIS Arc Macro Language scripts (AMLs), called Flood Mapper (Leslie Arihood, U.S. Geological Survey, written commun., March 2009). These AMLs were used to delineate areas of flood inundation in the June 2008 floods in Indiana (Morlock and others, 2008). The program requires a grid of the DEM and a point coverage representing the HWMs. This project was fortunate to have high-resolution (3-6 ft horizontal grid spacing and $30 \mathrm{~cm}$ vertical accuracy), LiDAR-derived DEMs of all study areas with the exception of a small part of the Newaukum River near the mouth. This small area was not included in the flood inundation map for the Newaukum River. LiDAR grids were obtained from the Puget Sound Lidar Consortium (http://pugetsoundlidar.ess.washington.edu/ index.html). A portion of the LiDAR grid for the Newaukum
River reach was obtained from Lewis County (Matthew Hyatt, Lewis County Public Works, written commun., December 2009).

The following general steps, which are listed in the order in which they were performed, were used to develop the flood inundation maps:

1. Created a stream section: A stream arc representing the main channel centerline was created in the GIS program with nodes defining the beginning and end of the mapping area. Additional nodes were then added to the stream arc at a user-specified interval.

2. Assigned elevations: Water-surface elevations were interpolated for each individual stream arc. The user assigned the upstream and downstream elevations for a set of stream arcs based on the nearby HWMs, and the program then interpolated elevation for each individual node in the set of stream arcs. During this step, the user asserted his or her judgment to select the most representative HWMs and disregarded other HWMs on the basis of trends in the slope defined by the HWMs and the quality of individual HWMs.

3. Created cross sections: The hydrologist added cross sections across the valley. Each cross-section line represented a line of equal, potential peak water-surface elevation and generally was perpendicular to the direction of flow. If a ponded area away from the main channel was filled by the flood due to the breaching or overtopping of a levee or low-spot in a roadway, a curved cross-section line may have been used to keep the water surface of the flooded area at the same elevation as the breach point even though the area may be upstream or downstream of the breach point. The endpoints of the cross-section lines determined the extent of the flood-inundation analysis. Note that the lines are called "Potential water-surface contours" on the final maps, and they were not drawn at equal-elevation intervals as is common for contours on topographic maps.

4. Created a water surface: The cross-section lines were converted to a point coverage at the hydrologistselected interval along the lines and each point carried the elevation value of its original line attribute. The point coverage was then used to create a surface with a Triangular Irregular Network (TIN) interpolator (a trend surface-interpolator option is available, but only the TIN option was used in this project). On the shoreward side of exposed continuously intact levees or roadways acting as levees, the true flood elevation may not have been the peak water-surface elevation on the stream side of the levee, but it may likely have been the peak water-surface elevation at the closest levee breach or overtopping point. In these cases, a TIN was created outside the flood mapper program with $\mathrm{ARC} / \mathrm{INFO}{ }^{\circledR}$, using the barrier 
option in the CREATETIN command and a line coverage of the levee or roadway that is acting as a barrier. In a similar situation, a low-lying area on the shoreward side of a barrier and within the area defined by the cross sections that did not get flooded would have been flooded by the standard flood-mapper procedure. These areas were either excluded with a GIS mask of the area or the TIN was processed outside of the flood mapper program with a BNDRY_COV option that defines the boundaries of processing with a polygon coverage that did not include the protected area. The final maps show or note any barrier lines or GIS exclusion areas that were used.

5. Created flood surface and depth grids: The flood-mapper AML created both the flood surface and depth grids with the TIN created in the previous step by subtracting the terrain elevation (DEM) from the water-surface elevation TIN.

6. Created a flood profile: Two operations were conducted to construct the flood profile. First, the river miles of the upstream and downstream ends of the stream coverage were specified in the flood mapper program, and second, the HWMs used to produce the flood surface were moved close to the stream coverage. Once these activities were completed, the profile was constructed to define the stream elevation at the location of the HWMs.

Two mapping products and one profile graph were produced by the process described above for each study reach except for the Tolt and Snoqualmie River near Carnation reaches, which were combined on one map because of their proximity to one another. These maps and graphs (figs. 28-35 and pls.1-7) include the final flood-inundation map, a map of the HWMs that were used in defining the peak water surface, and a profile graph of the peak water surface. The HWM maps show the HWMs that were used in the analysis and those that were not. The HWM elevations are shown in this map overlain on a colored-shaded relief map of the study reach and valley. The inundation maps show the potential water-surface contours that were used to derive the two-dimensional peak water surface used in the analysis. HWM locations and the color-shaded flood-depth information that defines the area of inundation as well as the depth also are included on the maps. The background map for the inundation maps is a digital aerial orthophotograph provided by the National Agricultural Imagery Program (Mathews, 2008). The maps and profiles are available on the project web site under the "Maps" menu.

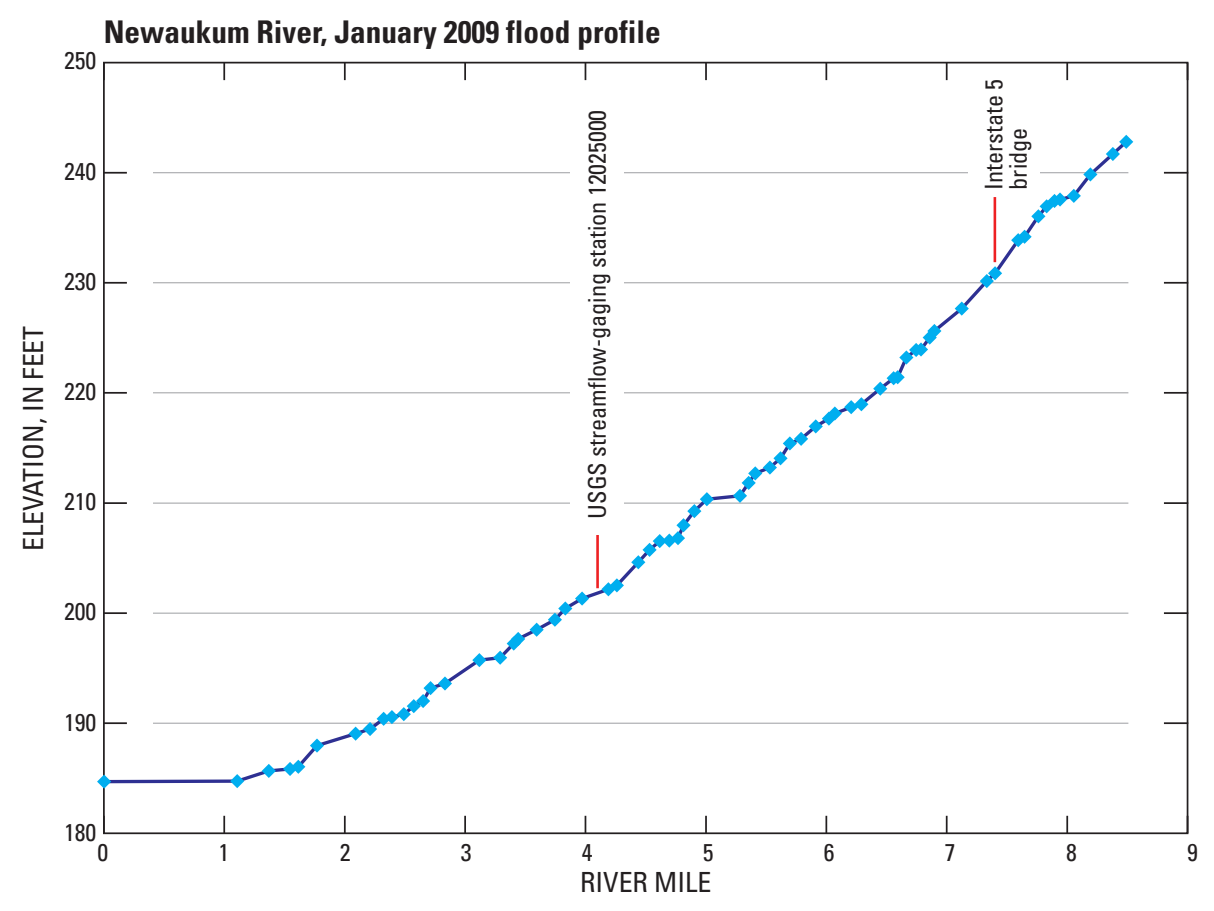

Figure 28. Flood profile of the January 2009 flood on the Newaukum River reach in western Washington. 


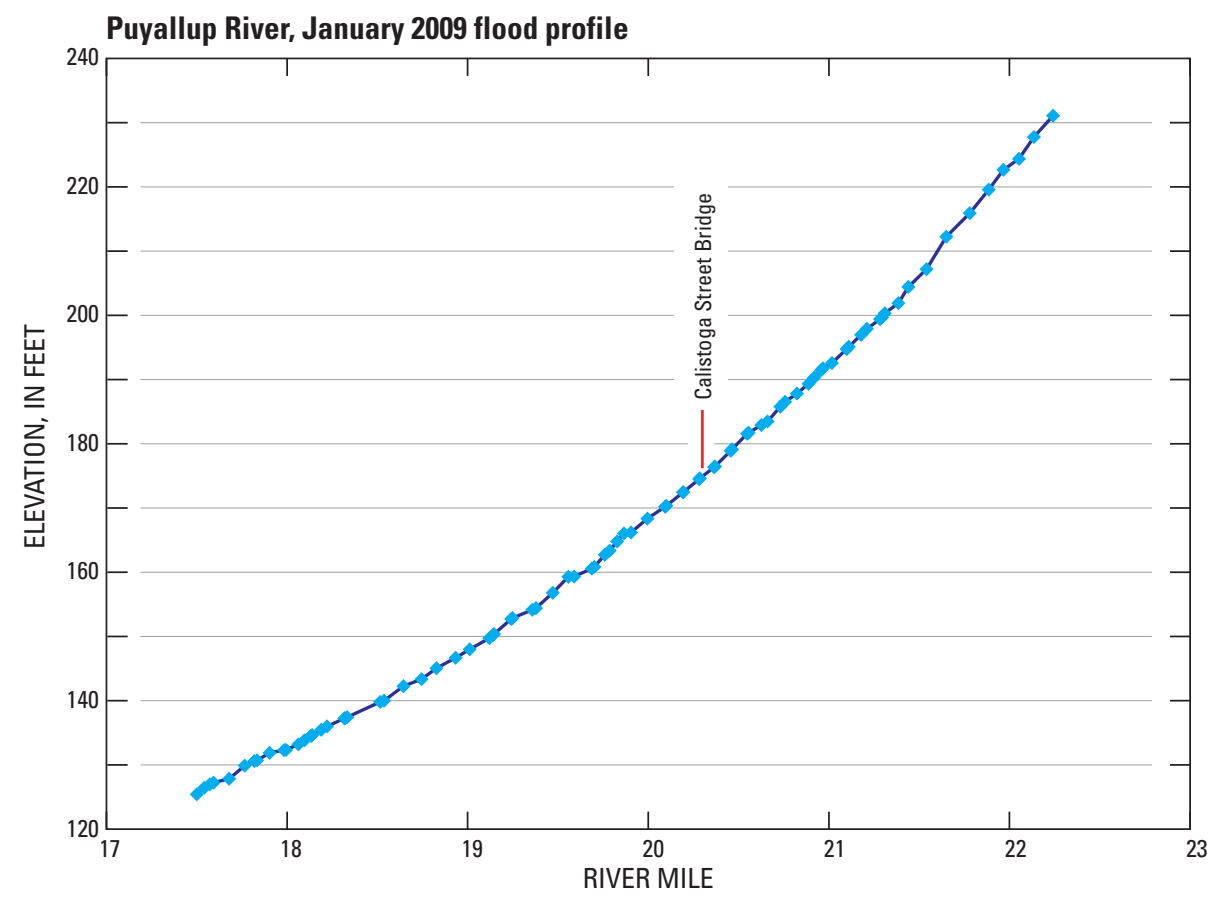

Figure 29. Flood profile of the January 2009 flood on the Puyallup River reach in western Washington.

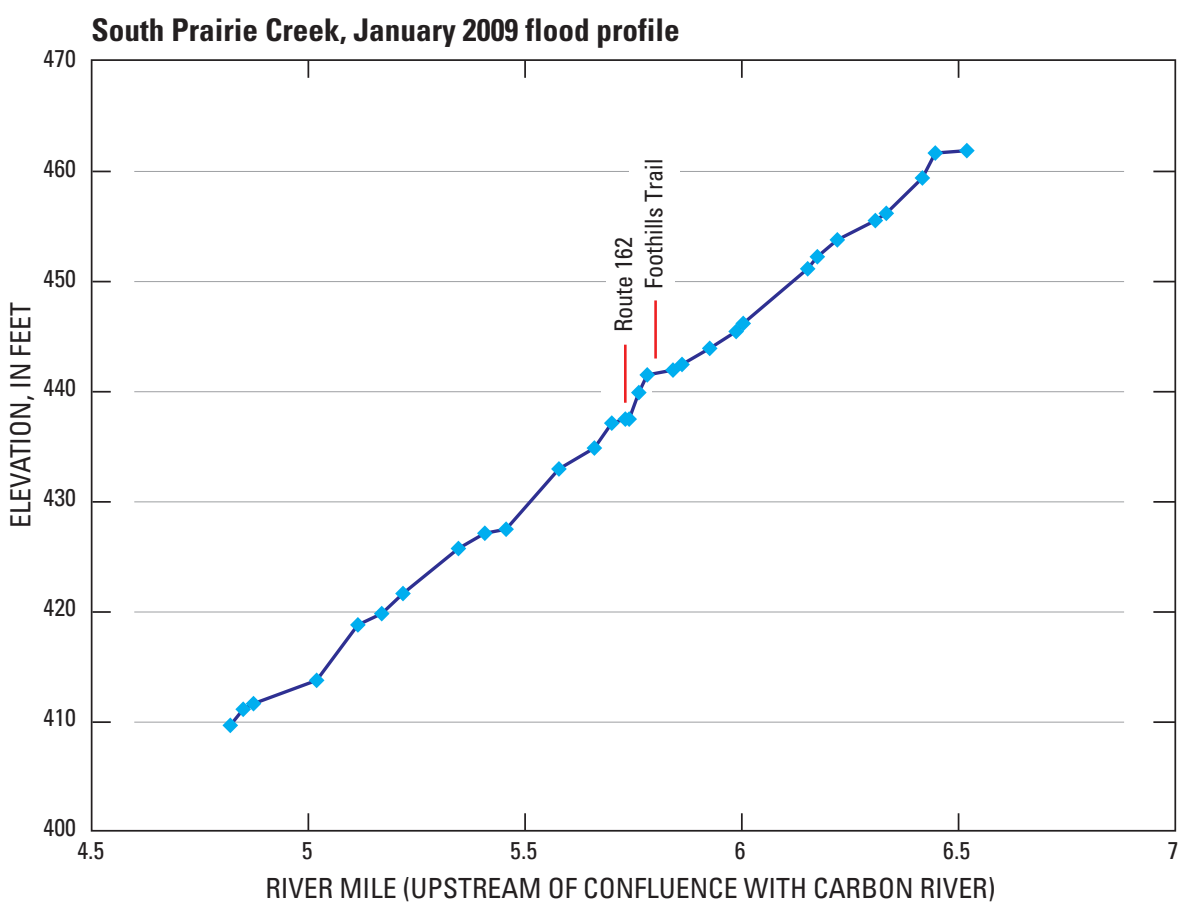

Figure 30. Flood profile of the January 2009 flood on the South Prairie Creek reach in western Washington. 


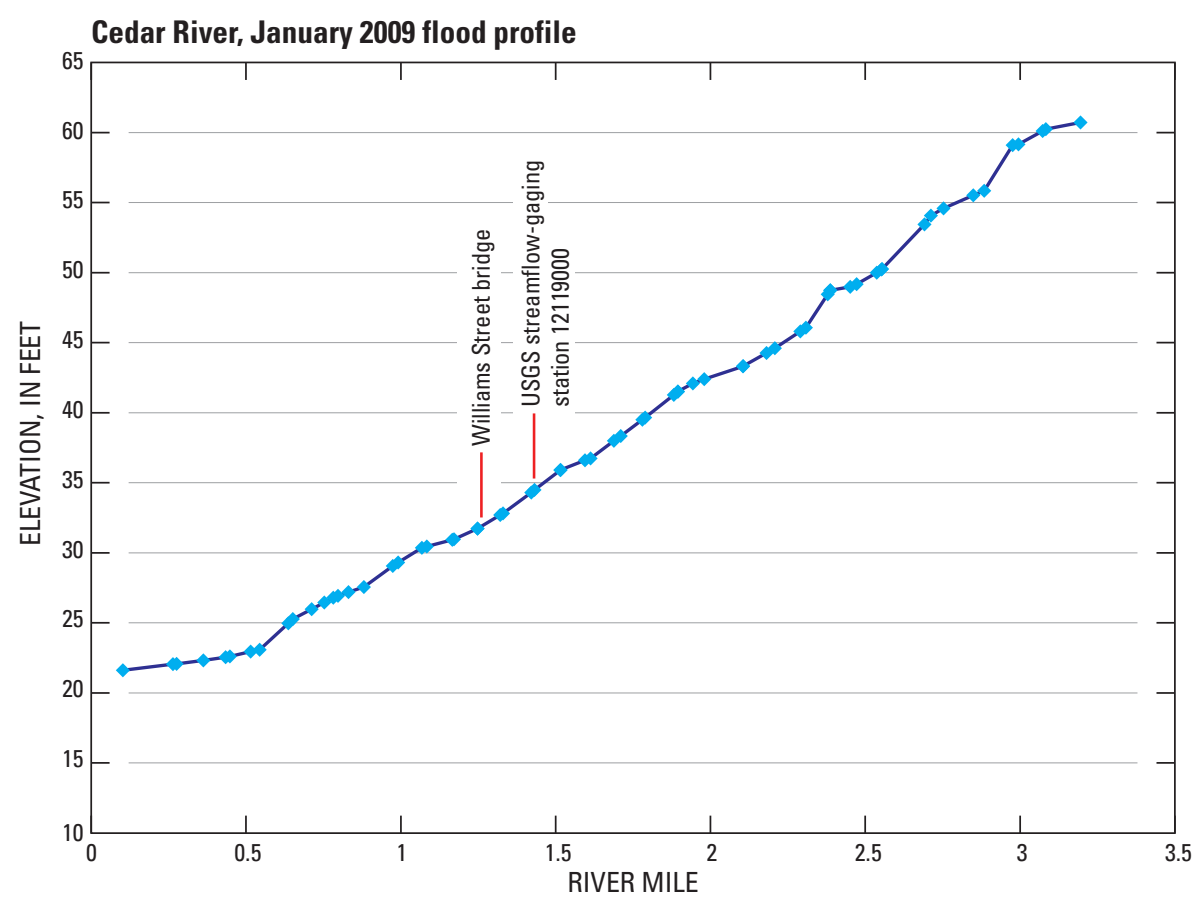

Figure 31. Flood profile of the January 2009 flood on the Cedar River reach in western Washington.

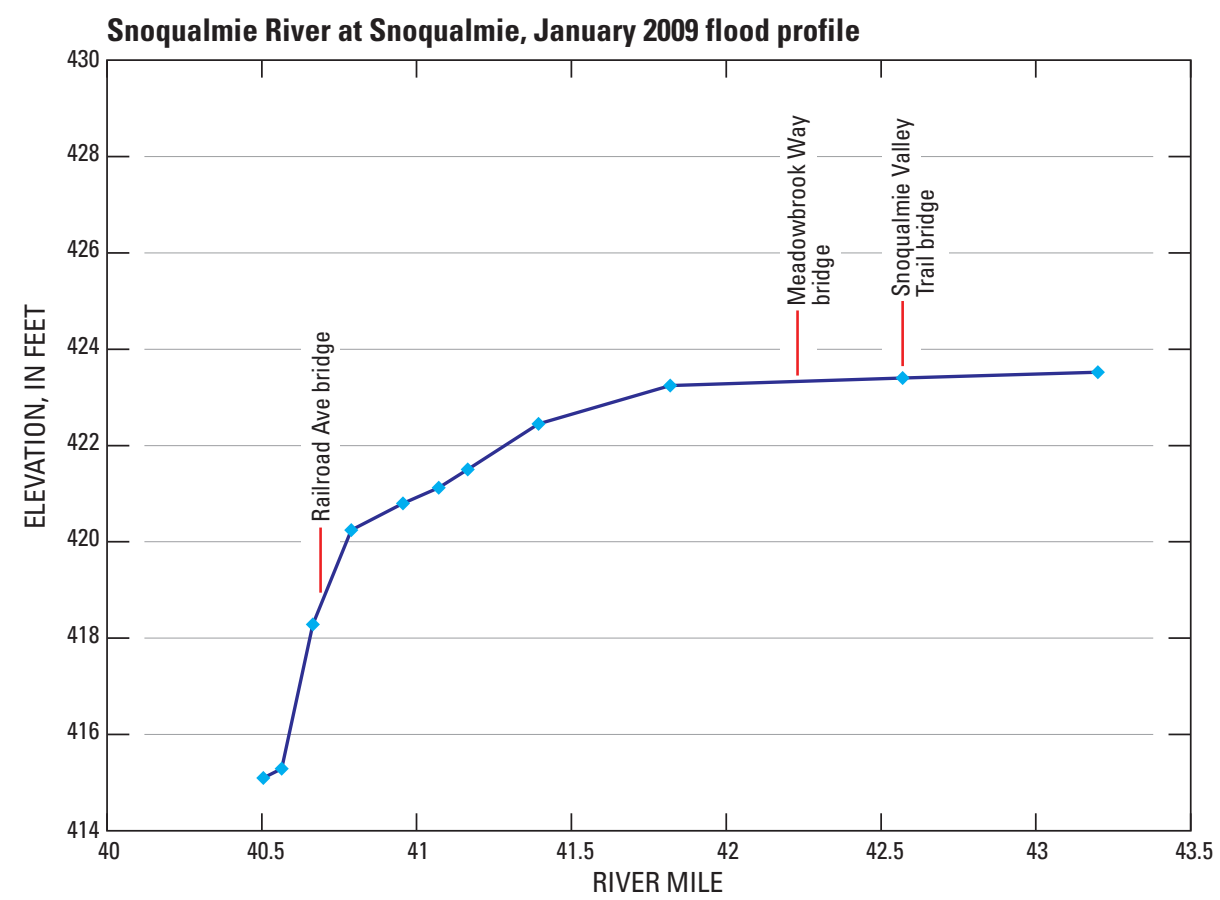

Figure 32. Flood profile of the January 2009 flood on the Snoqualmie River at Snoqualmie reach in western Washington. 


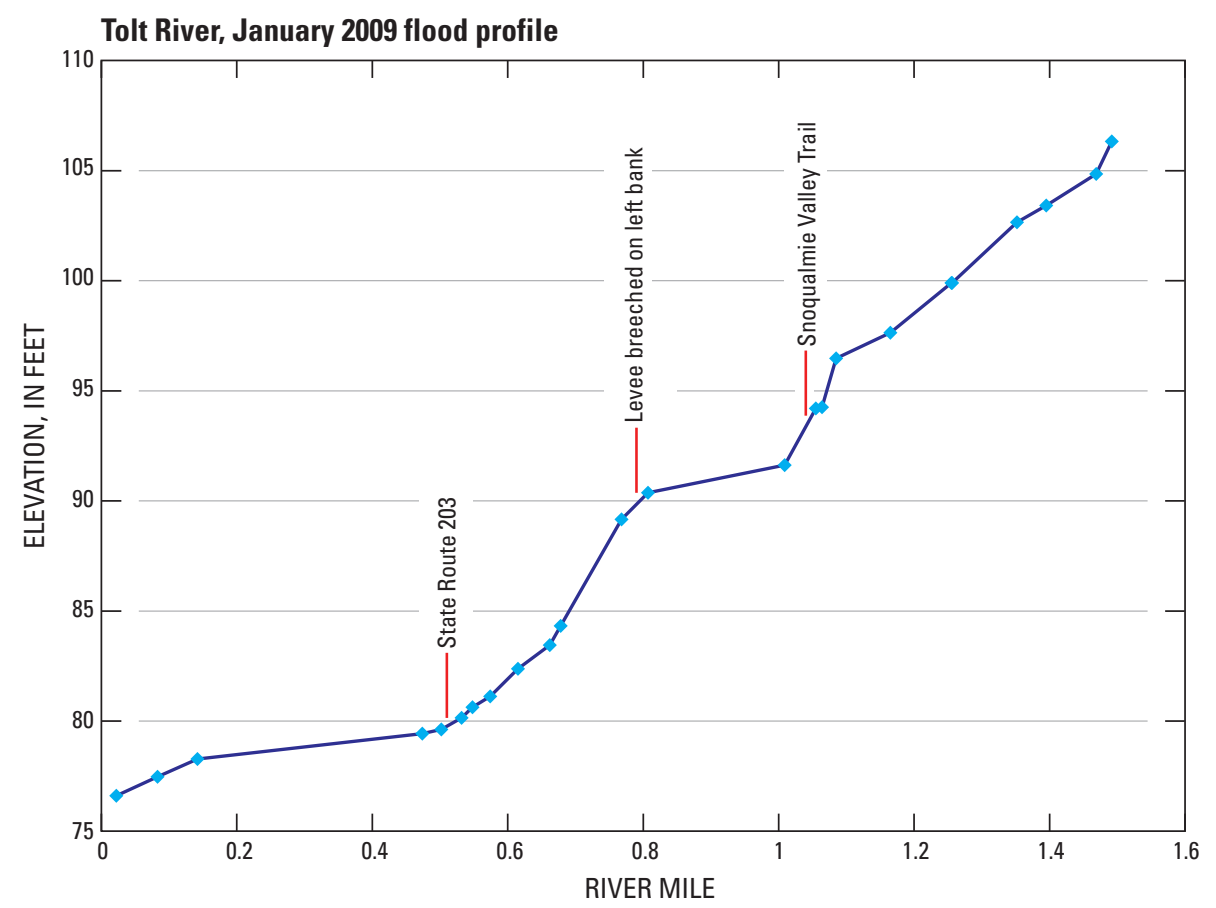

Figure 33. Flood profile of the January 2009 flood on the Tolt River reach in western Washington.

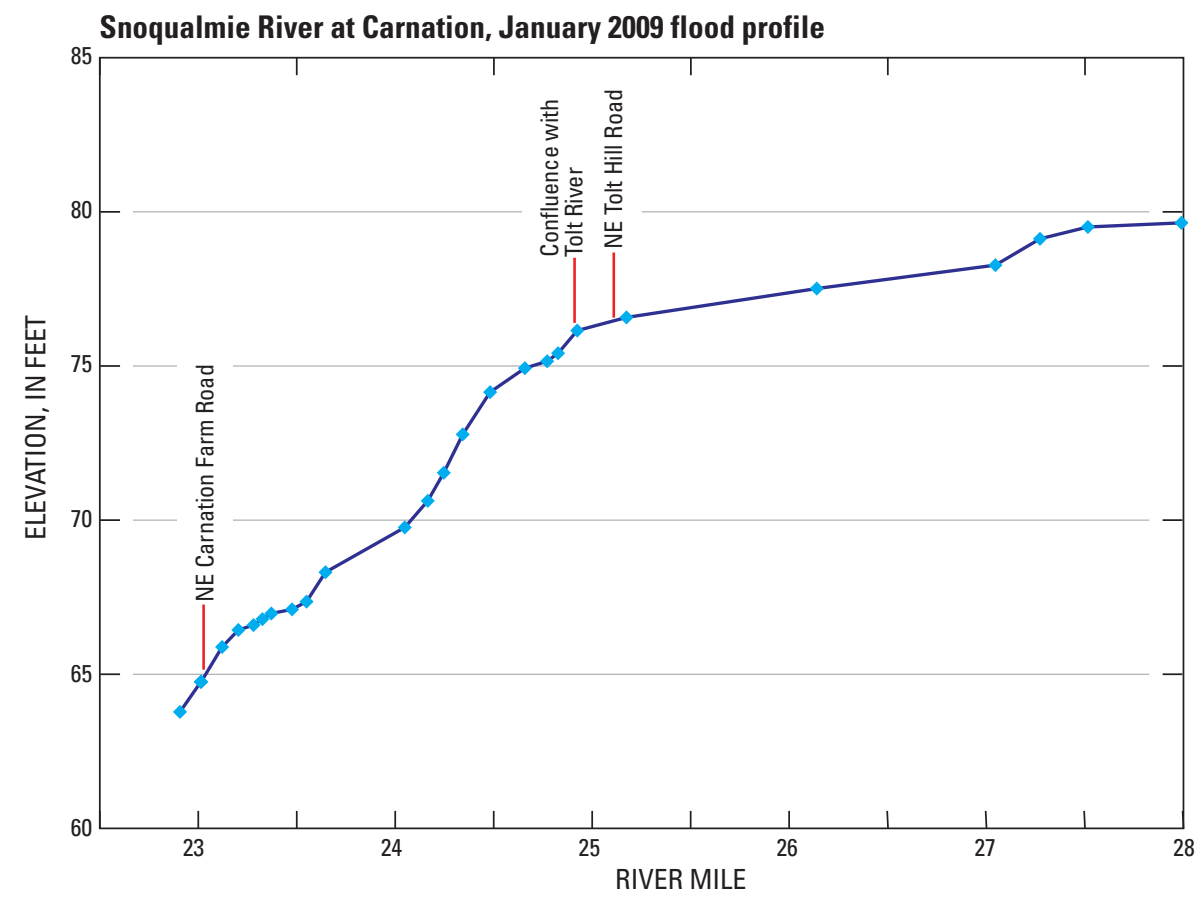

Figure 34. Flood profile of the January 2009 flood on the Snoqualmie River at Carnation reach in western Washington. 


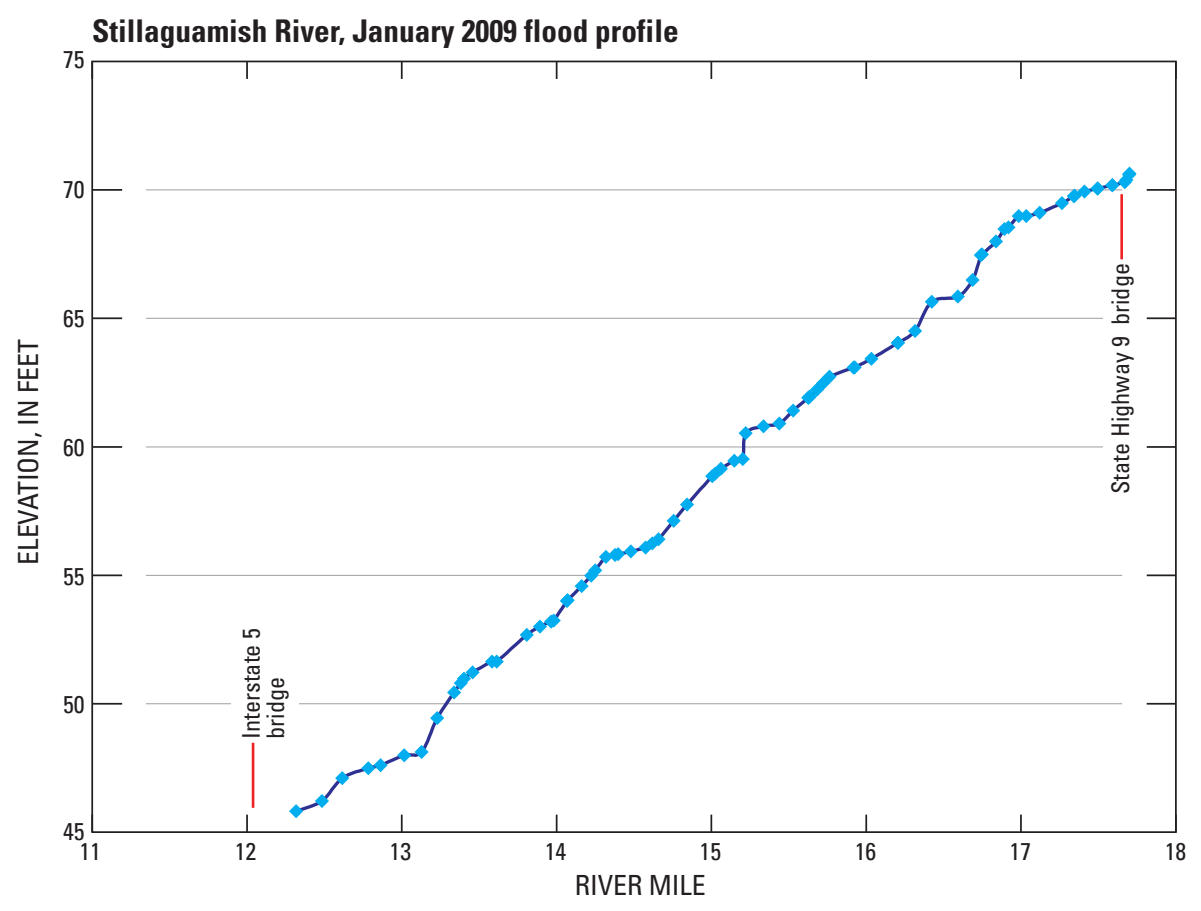

Figure 35. Flood profile of the January 2009 flood on the Stillaguamish River reach in western Washington.

Field notes by USGS personnel taken during the HWM survey commonly included information on levee breaches and accounts by local property owners of the source and direction of the floodwaters. Aerial photographs of the floods acquired near the time when the river crested also were often available. In some cases, these anecdotal pieces of information proved to be vital to understanding the flow dynamics and methods used for constructing the flood maps. Each preliminary map was sent to at least one local government representative for review (see section "Acknowledgments"). Adjustments were made by revising the cross sections, adding barriers to the TIN, and making GIS masks to exclude certain areas.

Two examples, one simple and one complex, of the inundation mapping products are discussed here to illustrate the procedure and results. The flooding on the lower Cedar River was confined to the immediate flood plain of the river with no indication of separated flows or levee breaches (pl. 4B). The lower Cedar River flood map represents a simple example of the flood-mapper procedure that was a straightforward application with little adjustment after the first map was produced. The profile is fairly regular (fig. 31) for most of the reach (slope $=0.0027 \mathrm{ft} / \mathrm{ft}$ ) and then flattens out at the downstream end of the reach (slope $=0.0006 \mathrm{ft} / \mathrm{ft}$ ). The lower, flatter slope is likely due to backwater influences of Lake Washington. Slight irregularities in the profile may be due to errors in the selection of the HWMs such as debris-pile HWMs that settled after the flood, surveyed elevations that may be in error up to $0.35 \mathrm{ft}$, channel-geometry configurations such as constrictions in the channel that tend to cause local ponding upstream of the constriction and steep gradients through the constriction, or section controls on water elevation such as log jams or weirs.

The application of the flood-mapping procedure to the flooding on the Snoqualmie River at Snoqualmie was a more complex one, which required many iterations before it was considered final (pl. 5). The analysis is subjective, however, and alternative interpretations could be made. The resulting flood inundation map relied on personal accounts of landowners and City of Snoqualmie officials who provided a map of the area of inundation within the city limits that was compiled from local accounts of the flooding. Those areas of cross hatching on the flood-inundation map (pl. 5B) labeled as "Additional areas of potential flooding" are areas that the City of Snoqualmie labeled as flooded, but our own analysis showed as remaining dry. Several landowners in the city related the same story, as did city officials that the floodwaters came from the south and not from the main stem of the Snoqualmie River. One resident on SE 2nd Ave, a road on the south side of the river that runs parallel to it near RM 42, reported a standing wave on the riverside of SE 2nd Ave and that water was flowing from the south toward the main channel of the river. This information supports the pattern of potential water-surface contour lines in the final inundation map (pl. 5B), which shows a steep gradient of the water surface defined by the contour lines that were drawn in order to accommodate the values of the HWMs surveyed in the area. 
The water-surface profile (fig. 32) is virtually flat in the upper portion of the reach because the general direction of flow at the time of the peak seemed to be perpendicular to the main channel and some of the water was likely going into temporary storage in the Borst Lake area. The HWMs in this area are lower on the north side of the river than the HWMs directly across the river to the south. Floodwaters likely broke out of the main channel upstream of the study reach and flowed throughout town (Snoqualmie) and in Kimball Creek before re-entering the main channel in the lower portion of the study reach. It was beyond the scope of this study to investigate this hypothesis more thoroughly, which would have required surveying additional HWMs throughout the valley. The water-surface profile steepens in the mid to lower section of the reach as all the water must pass through a confined portion of the reach before Snoqualmie Falls. The lowest portion of the study reach is just upstream of the falls, where the water-surface profile becomes nearly flat again before flowing over the narrow sectional control of the falls.

\section{Summary}

The January 2009 flood in western Washington was caused by prolonged precipitation that intensified for 3 days beginning on January 6 , with contributions of lowland snowmelt. Widespread flooding set peak-of-record discharges at many U.S. Geological Survey's long-term streamflow-gaging stations in the region. The depth and area of inundation from this flood were mapped for eight stream reaches selected by the Federal Emergency Management Agency (FEMA). The flooding at all but two of the selected reaches had annual exceedance probabilities ranging from 0.02 to 0.005 , equivalent to return periods ranging from 50 to 200 years.

The U.S. Geological Survey (USGS) surveyed high-water marks (HWMs) on both banks of the eight reaches during the summer of 2009. The HWMs initially were flagged and documented with a hand-held global positioning system (GPS) unit, photographs, and field descriptions. Subsequently, a survey-grade GPS was used to survey the HWMs directly or to establish nearby temporary benchmarks so that accurate elevations of the marks could be obtained with a laser rangefinder, a level, or a total station. Expected errors in the surveyed elevations range from 0.17 to 0.35 feet. HWM elevations and quality information were provided via a Google Maps (C) application developed to display all of the HWM data on an interactive mapping tool.
Geographic information system (GIS) analysis techniques were used with the HWM elevations and Light Detection and Ranging (LiDAR)-derived Digital Elevation Models (DEMs) of the study reaches to produce maps of the area of flood inundation and graphs of profiles of the water surface at the peak of the flood. Floods confined to the stream channel and (or) the immediately adjacent flood plain, with no major separations of flow, were relatively easy to map on the basis of the HWM data. More common, however, were widespread areas of inundation with separated flows, the mapping of which required interpretation of aerial photographs, reports from local landowners and government officials, and hydrologic judgment. For each of the study reaches, two maps and one water-surface profile were produced. One map shows the HWMs used in the analysis on a colored relief background, and the other map shows the potential water-surface contours used in the analysis along with the flood depth on a digital aerial orthophotograph background.

\section{Acknowledgments}

We thank the residents of Lewis, Pierce, King, and Snohomish Counties who graciously allowed us access to the streams through their properties to flag and survey the high-water marks. They also were often helpful in showing us the extent of flooding and where the floodwaters came from. This information provided us with critical insight to ensure that the flood maps were correct. We also thank the following local government representatives who viewed the preliminary maps and corrected them as needed: Christopher Hagedorn, Public Works Director, City of Carnation-Snoqualmie and Tolt Rivers near Carnation; Kenneth Wolfe, Building Official, City of Orting _-Puyallup River near Orting; Mel Soares, GIS Analyst, City of Snoqualmie-Snoqualmie River near Snoqualmie; Chris Nelson, River Engineer, Surface Water Management Division, Snohomish County_Stillaguamish River near Arlington; Max Albert, Stillaguamish Flood Control District - Stillaguamish River near Arlington; Bobbi Boone and Robert Nacht, City of Chehalis - Newaukum River near Chehalis; Matt Hyatt, GIS Manager, Lewis County Public Works-Newaukum River near Chehalis; Anthony Cauldwell, Project Manager, Town of South Prairie-South Prairie Creek at South Prairie; Peggy Levesque, Mayor, Town of South Prairie-South Prairie Creek at South Prairie. 


\section{References Cited}

Lumia, Richard, Burke P.M., and Johnston, W.H., 1987, Flooding of December 29, 1984 through January 2, 1985 , in northern New York State, with flood profiles of the Black and Salmon Rivers: U.S. Geological Survey Water-Resources Investigation Report 86-4191, 53 p.

Mathews, Louise, 2008, National Agriculture Imagery Program (NAIP) Information Sheet: U.S. Department of Agriculture Information Sheet accessed January 2009 at http://www.fsa.usda.gov/FSA/apfoapp?area=home\&subject $=$ docs\& topic $=$ inf.

Morlock, S.E., Menke, C.D., Arvin, D.V., and Kim, M.H., 2008, Flood of June 7-9, 2008, in central and southern Indiana: U.S. Geological Survey Open File Report 2008-1322, 15 p., 3 app.

National Oceanic and Atmospheric Administration, 2009, Climatological data Washington: Asheville, N.C., National Oceanic and Atmospheric Administration data report, v. 113 , no. 1,31 p.

Schrock, Gavin, 2006, RTN-101-An introduction to network corrected real-time GPS/GNSS (Part 1): The American Surveyor, September, accessed January 25, 2010, at: http:// www.amerisurv.com/PDF/TheAmericanSurveyor_SchrockRTN101Part1_September2006.pdf.
Shick, Larry, 2009, The impact of atmospheric rivers on flooding in Western Washington, in Conference on Exploring New Hydrologic Warning Frontiers, Proceedings: Vail, Colorado, May 2009, National Hydrologic Warning Council accessed January 2010 at http://documents. clubexpress.com/documents.ashx?key=neOEPp1nbSAnID Q2vr\%2f7CDVyOr21LwlpjgQqNHB631Rd84CnHlffprHBg KuW\%2fngI.

Sumioka, S.S., Kresch, D.L., and Kasnick, K.D., 1998, Magnitude and frequency of floods in Washington: U.S. Geological Survey Water-Resources Investigations Report 97-4277, $91 \mathrm{p}$.

Taylor, George, 2002, Isopluvial boundaries for western Washington (rainfall intensity data): Oregon State University database, accessed July 23, 2010, at http://www. wsdot.wa.gov/mapsdata/geodatacatalog/Maps/250k/osu/ precipevents.htm.

U.S. Water Resources Council, 1981, Guidelines for determining floodflow frequency: U.S. Water Resources Council Bulletin 17B, 183 p. 
Publishing support provided by the U.S. Geological Survey

Publishing Network, Tacoma Publishing Service Center

For more information concerning the research in this report, contact the Director, Washington Water Science Center

U.S. Geological Survey

934 Broadway, Suite 300

Tacoma, Washington 98402

http://wa.water.usgs.gov 
